DOI: $10.15393 /$ j10.art.2019.4301

УДК 003+930.25

М. В. Заваркина

Петрозаводский государственный университет

(Петрозаводск, Российская Федерация)

mvnikulina@mail.ru

Т. В. Панюкова

Петрозаводский государственный университет

(Петрозаводск, Российская Федерация)

aurinko75@mail.ru

Н. А. Тарасова

Институт русской литературы (Пушкинский Дом) РАН

(Санкт-Петербург, Российская Федеращия)

nsova74@mail.ru

\title{
Графические особенности рукописей Достоевского (по материалам записных книжек и тетрадей 1862-1865 гг.)*
}

\begin{abstract}
Аннотация. В статье представлены предварительные результаты графического анализа текста, полученные на материале рабочих тетрадей Достоевского первой половины 1860-х гг., а именно «второй» и «третьей» записных книжек писателя и заполнявшейся одновременно с ними одной из его записных тетрадей (ОР РГБ. Ф. 93.I.2.7, 93.І.2.8; РГАЛИ. Ф. 212.1.3). Создаваемая информационная база данных по графике Достоевского может стать эффективным инструментом анализа «трудных чтений» в автографах писателя. Рассмотрена возможность применения двух сложившихся в достоевсковедении способов репрезентации текстов рабочих тетрадей Достоевского при графическом анализе отдельной группы записей из этих тетрадей, относящихся к расчетам и издательской деятельности Достоевского. Комплексное исследование данной малоизученной группы записей из нескольких ведущихся одновременно тетрадей позволило выявить некоторые их общие характеристики. Отдельной таблицей показаны промежуточные результаты графического анализа цифр в рукописях Достоевского, дополняющие составленный в прошлом году алфавит начертаний букв.

Ключевые слова: Ф. М. Достоевский, рукописное наследие, записные книжки, записные тетради, текстология, графика, информационная база начертаний букв, эдиционная практика
\end{abstract}

Об авторах: Заваркина Марина Владимировна - кандидат филологических наук, специалист WEB-лаборатории Института филологии, Петрозаводский государственный университет (пр. Ленина, 33, г. Петрозаводск, Республика Карелия, Российская Федерация, 185910); Панюкова Татьяна Викторовна - ведущий редактор Издательства ПетрГУ, Петрозаводский государственный университет (пр. Ленина, 33, г. Петрозаводск, Республика Карелия, Российская Федерация, 185910); Тарасова Наталья Александровна - доктор филологических наук, ведущий научный сотрудник, Институт русской литературы (Пушкинский Дом) РАН (наб. Макарова, 4, г. Санкт-Петербург, Российская Федерация, 199034)

Дата поступления: 01.10.2019

Дата публикации: 06.12.2019

(C) М. В. Заваркина, Т. В. Панюкова, Н. А. Тарасова, 2019 
Для цитирования: Заваркина М. В., Панюкова Т. В., Тарасова Н. А. Графические особенности рукописей Достоевского (по материалам записных книжек и тетрадей 18621865 гг.) // Неизвестный Достоевский. - 2019. - № 4. - C. 84-138. DOI: 10.15393/j10. art.2019.4301

$\mathrm{H}$ астоящая публикация включает предварительные результаты, полученные на материале, относящемся к первой половине 1860-х гг.:

1) так называемая «вторая» записная книжка писателя 1862-1864 гг. ${ }^{1}$, хранится в ОР РГБ. Ф. 93.I.2.7 (далее $3 K_{2}$ );

2) так называемая «третья» записная книжка писателя 1864-1865 гг., хранится в ОР РГБ. Ф. 93.I.2.8 (далее $3 K_{3}$ );

3) записная тетрадь 1864-1865 гг., хранится в РГАЛИ. Ф. 212.1.3 (далее 3Т).

Записные книжки и тетради Достоевского традиционно определяют как «творческие дневники» писателя: «В записных тетрадях Достоевского 60-х годов запечатлен важный этап творческого пути писателя, когда публицистические проблемы и образы органически вошли в его художественные произведения» [Розенблюм, 1981: 85]. Указанные выше книжки и тетрадь содержат публицистические замыслы и наброски, расчеты, связанные с делами журналов «Время» и «Эпоха», записи долгов и хозяйственных расходов, а также черновые материалы романа «Преступление и Наказание», наброски повести «Двойник», фельетона «Офицер и нигилистка» и рассказа «Крокодил». Отдельное место занимает разработка «Объявлений» о подписке на журналы «Время» и «Эпоха».

Бо̀льшая часть записей, особенно в записных книжках, сделана карандашом, который местами стерся и с трудом поддается прочтению. Каллиграфических записей, которыми изобилуют более поздние записные тетради Достоевского, в исследуемых рукописях немного, в основном каллиграфические записи и рисунки встречаются в 3Т. Кроме того, в данной тетради, чтобы указать на связь записей, Достоевский использует целую систему знаков (крестики, кружочки, цифры): «Эти элементы графики, так же как характер почерка, цвет чернил и т. д., помогают и исследователю читать тетради Достоевского в порядке их заполнения» ([Розенблюм, 1981: 7]; см. также: [Тарасова, 2016]).

По мнению Л. М. Розенблюм, «заводя небольшие по размеру книжки, Достоевский вначале предназначал их, очевидно, для личных, деловых и литературных заметок, наскоро фиксирующих мысли и впечатления, которые могла не удержать память. Но очень скоро, в первой же книжке, появляются пространные записи, сделанные отнюдь не наспех, а аккуратным почерком, чернилами, - признак сосредоточенной работы писателя» [Розенблюм, 1981: 12]. Стоит добавить, что характер заполнения $3 K_{2}$ и $3 K_{3}$ отличается: записей, сделанных аккуратным почерком, больше в $3 K_{2}$ - это наброски к переделке «Двойника» (хотя и с правкой) и записи, вызванные смертью М. Д. Достоевской (Исаевой), первой жены писателя, переросшие 
позднее в конспект статьи «Социализм и христианство»². $3 K_{3}$ Достоевский использовал в основном для записи адресов, расчетов, небольших заметок для публицистических замыслов; только на с. 2 сохранился полноценный набросок для «Политического обозрения». В большинстве своем все записи в $3 K_{3}$ сделаны наскоро, почти всегда карандашом, часто не точеным, с широким грифелем. Это связано с тем, что параллельно с этой книжкой Достоевский заводит две записные тетради бо́льшего формата, где идет уже настоящая творческая работа над текстами будущих произведений.

\section{Материалы базы данных по графике Достоевского как средство анализа «трудных чтений»}

Создание информационной базы данных по графике Достоевского - необходимость, так как в уже вышедших изданиях текстов писателя немало исследовательских ошибок в прочтении рукописей, в связи с чем и современные издания нуждаются в систематизированной информации о почерке Достоевского и особенностях его графики в целом. Данная база могла бы стать в работе текстологов и специалистов по творчеству Достоевского эффективным средством анализа автографов, т. н. «трудных чтений», неразборчиво записанных слов.

Частично записи были воспроизведены впервые В. С. Нечаевой при составлении обширного тома «Описание рукописей Ф. М. Достоевского» [Нечаева, 1957]. Записные книжки были опубликованы в 1971 г. в 83 т. «Литературного наследства» (далее - ЛН), повторно в 1980 г. в 20 и 27 томах Полного собрания сочинений в 30 т. (далее - Д30). Последняя публикация не затронула адреса, которыми заполнены порой целые страницы обеих ЗК и 3 - они были опубликованы Т. И. Орнатской [Орнатская: 15-31] и позже в статьях Б. Н. Тихомирова [Тихомиров, 2017, 2018].

При повторной расшифровке записей $3 K_{2}$ и $3 K_{3}$ нами были обнаружены ошибки чтения рукописного текста публикаторами. Рассмотрим некоторые примеры с учетом характерных особенностей почерка писателя, уделяя внимание разнице между записями, сделанными карандашом и чернилами, а также созданными в спешке, с сокращениями, - и тщательно прописанными.

Чаще всего появляются ошибки в прочтении окончаний слов, особенно написанных карандашом. Достоевский, как и многие, имел обыкновение не прописывать окончания, и при публикации их нередко восстанавливают в редакторских скобках. Если конец слова прописан, то обычно нечетко, из-за чего и возникают неточности в прочтении. Например, на с. 3 3К читаем «Кохановская» вместо: «Кохановской» [Орнатская: 17] (см. Илл. 1). На данной странице записан адрес писательницы Н. С. Соханской (Кохановской). На с. 137-138 3К осталась запись, которая была предназначена в том числе для статьи, посвященной повести Кохановской «Рой Федосей Саввич 
на спокое», опубликованной в 1864 г. в газете «День» (№ 5-15, 1 февраля 11 апреля; см. письмо к брату от 5 марта 1864 г. - Д30; 28: 68-69, 396). Позже запись со с. 137 была отражена Достоевским в более развернутом виде в «Объявлении» об издании журнала «Эпоха» на 1865 г. (опубл.: Эпоха. 1864. № 8) [ЛН, т. 83: 190].

Илл. 1. С. $33 K_{2}$

Буква «я» в почерке Достоевского имеет различные написания: традиционное, с четким прописыванием петли, или более беглое - без петли. Концевой штрих может уходить вниз либо вообще отсутствовать (см. Табл. 1).

\begin{tabular}{|c|c|c|c|}
\hline № & Фото буквы & Фото контекста & Текст \\
\hline 1 & 2 & & $\begin{array}{l}16 \text { Апрголя } \\
\left(3 K_{2}, \text { с. } 1\right)\end{array}$ \\
\hline 2 & is & & $\begin{array}{l}\text { Ноября } \\
\left(3 K_{2}, \text { с. } 1\right)\end{array}$ \\
\hline 3 & (f) & 10 & $\begin{array}{c}10 \text { Іюля } \\
\left(3 K_{2}, \text { с. } 1\right)\end{array}$ \\
\hline 4 & 'is & Pruafus & $\begin{array}{l}\text { Статья } \\
\left(3 K_{2}, \text { c. } 6\right)\end{array}$ \\
\hline 5 & eces, & hpokeusmber: & $\begin{array}{l}\text { Проклятый } \\
\left(3 K_{2}, \text { с. 6) }\right.\end{array}$ \\
\hline 6 & bue & Icucn,besurtue & $\begin{array}{c}\text { Умственныя } \\
\left(3 K_{2}, \text { с. } 6\right)\end{array}$ \\
\hline 7 & ore & chonaeneberen's' & $\begin{array}{c}\text { монастырямб } \\
\left(3 K_{2}, \text { с. } 6\right)\end{array}$ \\
\hline 8 & eb'p & os kuresnanceb'f & $\begin{array}{l}\text { экономическія } \\
\left(3 K_{2}, \text { с. } 18\right)\end{array}$ \\
\hline
\end{tabular}

Табл. 1. Варианты написания строчной буквы «я» в $3 K_{2}$ 
В фамилии «Кохановская» мы наблюдаем еще один, нечастотный вариант написания конечной «я»: с петлей, у которой концевой штрих уходит вверх. При этом буква «а» окончания превратилась в еле заметную точку 一 это тоже особенность беглого почерка писателя. Подобное происходит и с другими гласными, ср. написания: «вы желчевикъ», «этотъ доносчикъ» (см. Илл. 2)

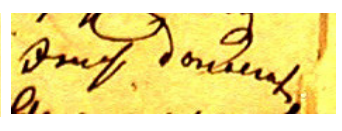

Илл. 2. Фрагменты с. $913 K_{1}$ и с. $183 K_{2}$

На с. 83 ЗК буква «я» с нижним концевым штрихом в возвратном постфиксе -ся при первой публикации книжки не была распознана, при этом произошла замена одного причастия другим (субстантивированным). Следует читать: «и идолопоклоняющихся своей личности» вместо: «и идолопоклонствующих своей личности» [ЛН, т. 83: 176]. См. Илл. 3.

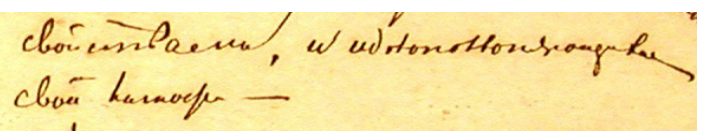

Илл. 3. Фрагмент с. $833 K_{2}$

Кроме того, конечную «я» в почерке Достоевского нередко путают с согласным «л», так как без четко прописанной петли две эти буквы становятся похожи. Но нужно иметь в виду, что букву «л» Достоевский писал чаще всего с верхним высоким выносным штрихом, хотя традиционное начертание тоже встречается (см. Табл. 2).

\begin{tabular}{|c|c|c|c|}
\hline № & Фото буквы & Фото контекста & Текст \\
\hline 1 & & & $\begin{array}{l}\text { 16. Апрпьля } \\
\left(3 K_{2}, \text { с. } 1\right)\end{array}$ \\
\hline 2 & & & $\begin{array}{c}10 \text { Іюля } \\
\left(3 K_{2}, \text { с. } 1\right)\end{array}$ \\
\hline 3 & & $\sin 0.0$ & $\begin{array}{c}\text { станиію Теплинку } \\
\left(3 K_{2}, \text { с. 3) }\right. \\
\text { карандаш }\end{array}$ \\
\hline
\end{tabular}




\begin{tabular}{|c|c|c|c|}
\hline 4 & cees, & hpokeusmber: & $\begin{array}{c}\text { Проклятый } \\
\left(3 K_{2}, \text { с. } 6\right)\end{array}$ \\
\hline 5 & hee. & huoxa, & $\begin{array}{c}\text { плоха } \\
\left(3 K_{2}, \text { c. } 6\right)\end{array}$ \\
\hline 6 & whe & ouvpluster & $\begin{array}{c}\text { она ходила } \\
\left(3 K_{2}, \text { с. } 6\right)\end{array}$ \\
\hline 7 & erb & moubto & $\begin{array}{c}\text { только } \\
\left(3 K_{2}, \text { с. } 6\right)\end{array}$ \\
\hline 8 & & сиуга & $\begin{array}{c}\text { слууги } \\
\left(3 K_{2}, \text { с. } 6\right)\end{array}$ \\
\hline
\end{tabular}

Табл. 2. Варианты написания строчной буквы «л» в $3 K_{2}$

Ha c. $223 K_{2}$ находим неточное прочтение правки конца слова, где также не распознана строчная «я». Следует читать: «-Г. Голядкинъ выз $[$ вавъ] $\{$ бьвая $\}$ на дуэль» вместо: «- Г. Голядкин [вызвав] вызвал на дуэль» [ЛН, т. 83: 179], (Д30; 1: 436) (см.: Илл. 4).

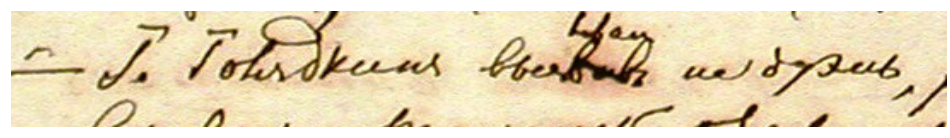

Илл. 4. Фрагмент с. $223 K_{2}$

На данном примере наблюдаем расхождение в прочтении не только конечной «я», написанной без традиционной петли, но и буквы «ы», которая в почерке Достоевского может иметь высокую верхнюю выносную линию. См. Табл. 3, примеры 4 и 7.

\begin{tabular}{|c|c|c|c|}
\hline № & Фото буквы & Фото контекста & Текст \\
\hline 1 & be & $f(\vec{m}) t$ & $\begin{array}{l}\text { вblרb3дz } \\
\left(3 K_{2}, \text { c. } 1\right)\end{array}$ \\
\hline 2 & tol & ugi clloukches: & $\begin{array}{c}\text { изб Москвы } \\
\left(3 K_{2}, \text { c. } 1\right)\end{array}$ \\
\hline 3 & mber & hpokeusmber: & $\begin{array}{c}\text { Проклятышй } \\
\left(3 K_{2}, \text { с. } 6\right)\end{array}$ \\
\hline 4 & tou & Icucn,bendire & $\begin{array}{c}\text { Умственныя } \\
\left(3 K_{2}, \text { с. } 6\right)\end{array}$ \\
\hline
\end{tabular}




\begin{tabular}{|c|c|c|c|}
\hline 5 & for & Preyers & $\begin{array}{c}\text { Tepeзы } \\
\left(3 K_{2}, \text { c. } 6\right)\end{array}$ \\
\hline 6 & bepe & nonaendeperens & $\begin{array}{c}\text { монастырямб } \\
\left(3 K_{2}, \text { с. } 6\right)\end{array}$ \\
\hline 7 & & Glevpedste & $\begin{array}{c}\text { Благородныя слезы } \\
\left(3 \mathrm{~K}_{2}, \text { с. 18) }\right.\end{array}$ \\
\hline
\end{tabular}

Табл. 3. Варианты написания строчной буквы «ы» в $3 K_{2}$

Из-за неразличения буквы «ы» в почерке писателя возникла и ошибка в прочтении фразы на с. 78 3К: «можно сказать науки есть въ высочайшей степени національны» (см. Илл. 5). В первой публикации: «можно сказать наука есть в высочайшей степени национальность» [ЛН, т. 83: 176].

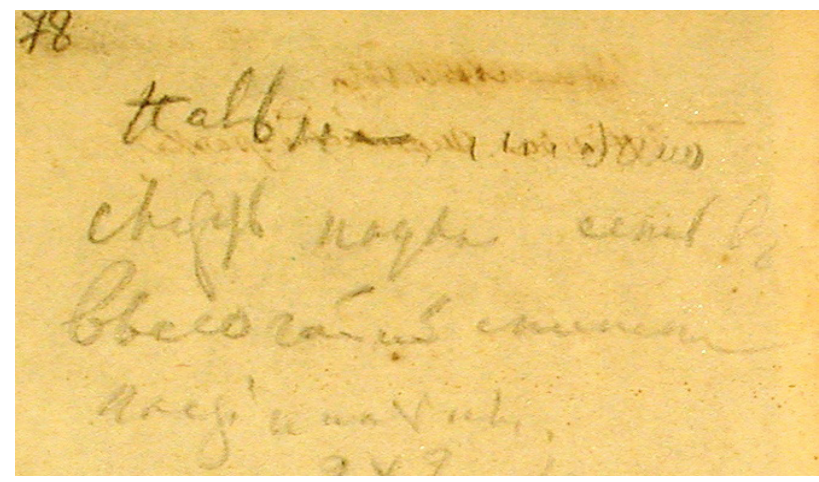

Илл. 5. Фрагмент с. $783 K_{2}$

На с. $423 K_{2}$ находим еще одну ошибку в расшифровке конца слова: суффикс деепричастия прочитывается как окончание причастия, при этом в ЛН добавляется суффикс -енн, в Д30 данный суффикс восстанавливается в редакторских скобках. Читаем: «взаимно уничтожая другъ для друга» вместо: «взаимно уничтоженные друг для друга» [ЛН, т. 83: 173], (Д30; 20: 172). (См. Илл. 6).

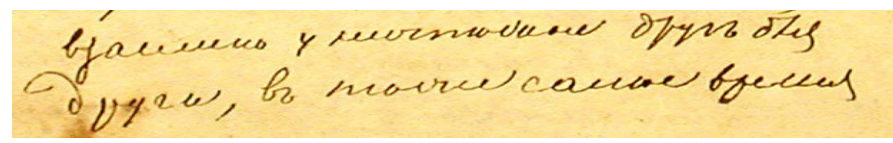

Илл. 6. Фрагмент с. $423 K_{2}$ 
Букву «я» на конце слов Достоевский часто пишет как букву «е» (см. Илл. 7) - это еще одна особенность почерка писателя. В примере ниже («Благородныя слезы») перед нами буква «я», что графически установить трудно (буква не прописана четко), но в данном случае выбор буквы соответствует языковой норме XIX в., согласно которой в окончаниях прилагательных ж. р. и ср. р. мн. ч. необходима была буква «я».

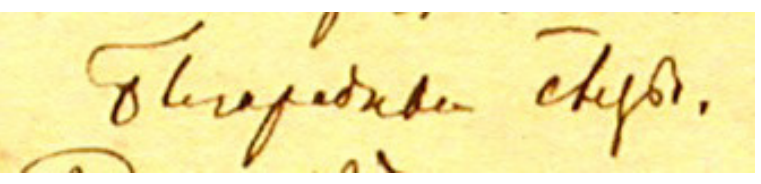

Илл. 7. Фрагмент с. $183 K_{2}$

Кроме того, в слове «уничтожая» (см. Илл. 6) не читается суффикс-енн: перед нами традиционное для почерка Достоевского написание буквы «ж», когда левый завиток отделен от правого небольшим пробелом (ср. Илл. 8).

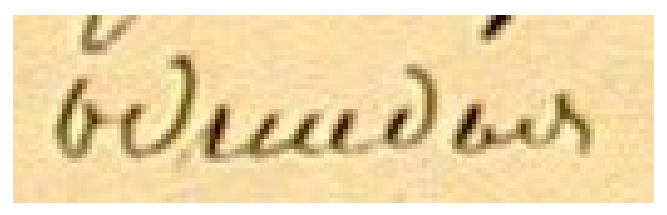

Илл. 8. «Ожидая». Фрагмент с. $653 K_{1}$

Ошибка могла возникнуть еще и потому, что в слове «уничтожая» не увидели букву «а», которая также нередко пишется Достоевским с верхним соединением и становится похожей на «о» (см. Илл. 9).

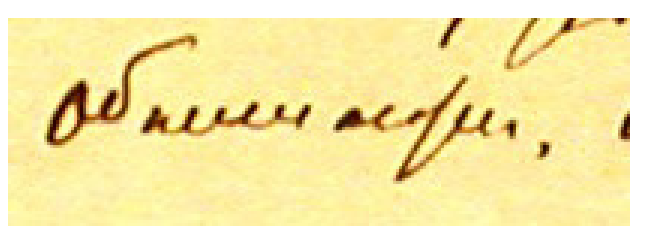

Илл. 9. «Обнимается». Фрагмент с. $183 K_{2}$

Следует сказать, что букву «а» в $3 K_{2}$ Достоевский прописывает чаще классически: со скруглением и концевым штрихом, находящимся в нижней части буквы (см. Табл. 4). 


\begin{tabular}{|c|c|c|c|}
\hline № & Фото буквы & Фото контекста & Текст \\
\hline 1 & & & $\begin{array}{c}\text { Харьковской } \\
\left(3 K_{2}, \text { с. } 3\right) \\
\text { карандаш }\end{array}$ \\
\hline 2 & & & $\begin{array}{c}\text { Тракту } \\
\left(3 K_{2}, \text { с. 3) }\right. \\
\text { карандаш }\end{array}$ \\
\hline 3 & 6 & & $\begin{array}{c}\text { нa } \\
\left(3 K_{2}, \text { с. 3) }\right. \\
\text { карандаш }\end{array}$ \\
\hline 4 & & & $\begin{array}{c}\text { станиію } \\
\left(3 K_{2}, \text { с. 3) }\right. \\
\text { карандаш }\end{array}$ \\
\hline 5 & & & $\begin{array}{l}\text { Надеждю } \\
\left(3 K_{2}, \text { с. 3) }\right. \\
\text { карандаш }\end{array}$ \\
\hline 6 & & & $\begin{array}{c}\text { Соханской } \\
\left(3 K_{2}, \text { с. 3) }\right. \\
\text { карандаш }\end{array}$ \\
\hline 7 & & & $\begin{array}{l}\text { Cmambя } \\
\left(3 K_{2}, \text { с. } 6\right)\end{array}$ \\
\hline 8 & & o jaces & $\begin{array}{l}\text { ороманть } \\
\left(3 K_{2}, \text { с. } 6\right)\end{array}$ \\
\hline 9 & & heore, & $\begin{array}{c}n \pi о x a \\
\left(3 K_{2}, \text { с. } 6\right)\end{array}$ \\
\hline 10 & $C_{w}$ & owyenter & $\begin{array}{c}\text { она ходила } \\
\left(3 K_{2}, \text { с. } 6\right)\end{array}$ \\
\hline 11 & & owewnter & $\begin{array}{c}\text { она ходила } \\
\left(3 K_{2}, \text { с. } 6\right)\end{array}$ \\
\hline 12 & Ha & sonaeneberen's & $\begin{array}{c}\text { монастьрямб } \\
\left(3 K_{2}, \text { с. } 6\right)\end{array}$ \\
\hline 13 & & huto & $\begin{array}{c}\text { Taאz } \\
\left(3 K_{2}, \text { c. } 6\right)\end{array}$ \\
\hline
\end{tabular}




\begin{tabular}{|c|c|c|c|}
\hline 14 & akt & $\begin{array}{l}\text { peseovas } \\
\text { qunadak }\end{array}$ & $\begin{array}{c}\text { Госnодаxъ } \\
\left(3 K_{2}, \text { с. 6) }\right.\end{array}$ \\
\hline 15 & & & $\begin{array}{c}\text { разговаривать } \\
\left(3 K_{2}, \text { с. } 6\right)\end{array}$ \\
\hline
\end{tabular}

Табл. 4. Варианты написания строчной буквы «а» в $3 K_{2}$

Схожая ошибка чтения (и по тем же причинам) возникла в предложении: «человпкъ переродится по Законамъ природы окончательно въ другую натуру, которая не женится и не посягаетъ» (см. Илл. 10). В первой публикации: «человек переродится по законам природы окончательно в другую натуру, который не женится и не посягает» [ЛН, т. 83: 174]. В сноске уточняется, что в рукописи: «которые».

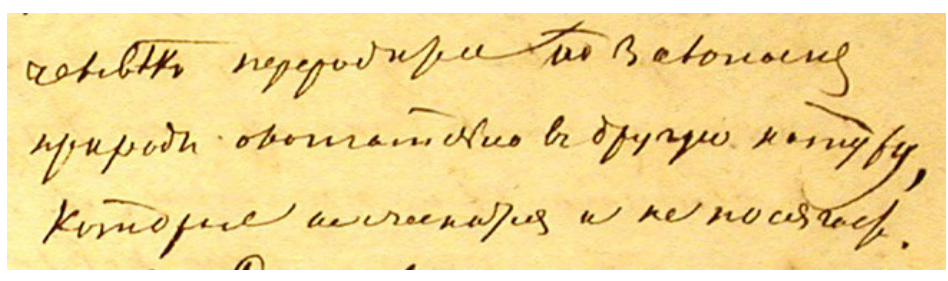

Илл. 10. Фрагмент с. $473 K_{2}$

Букву «ы» Достоевский никогда не пишет таким усеченным образом, обычно она узнаваема в его почерке (см. Табл. 3).

В ЛН (т. 83: 173) правильно прочитан фрагмент со с. 46: «...закона природы человпкъ достигаетъ развитіемъ»; ср. с ошибочным: «...закона природы человек достигает развития» (Д30; 20: 173). См. Илл. 11.

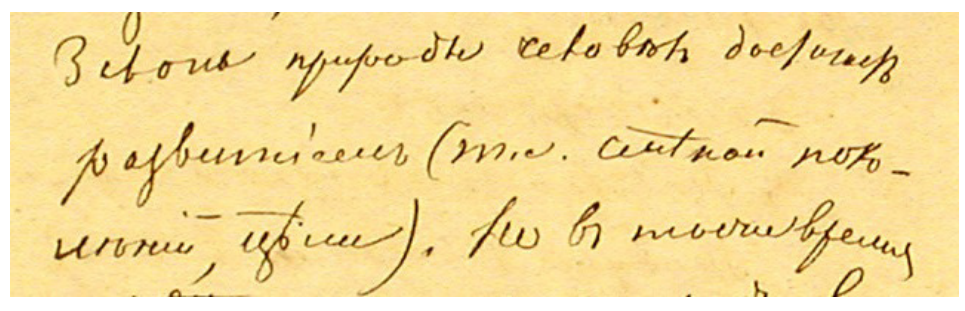

Илл. 11. Фрагмент с. $463 K_{2}$

В данном случае в Д30, по-видимому, опечатка, на что указывает несогласованность грамматических форм. Уточнение в скобках («т. е. смюной покольній, иъпли») является дополнительным указанием на Тв. падеж уточняемого слова. Букву «и» Достоевский чаще всего прописывает традиционно: с двумя параллельно стоящими вертикальными штрихами и плавным скругленным соединением (см. Табл. 5). 


\begin{tabular}{|c|c|c|c|}
\hline № & Фото буквы & Фото контекста & Текст \\
\hline 1 & w & 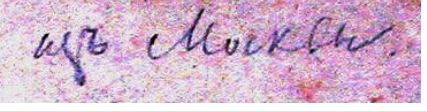 & $\begin{array}{l}\text { uзб Moсквы } \\
\left(3 K_{2}, \text { c. } 1\right)\end{array}$ \\
\hline 2 & $O C$. & $\begin{array}{l}\text { Amangito Men- } \\
\text { lurky, Hadered) } \\
\text { O.m. }\end{array}$ & $\begin{array}{c}\text { станцію Теплинку } \\
\left(3 K_{2}, \text { с. } 3\right) \\
\text { карандаш }\end{array}$ \\
\hline 3 & ees & 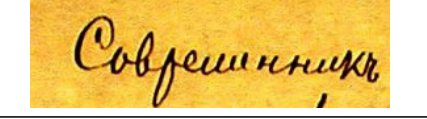 & $\begin{array}{c}\text { Современникъ } \\
\left(3 K_{2}, \text { с. } 6\right)\end{array}$ \\
\hline 4 & uta & oweryintes & $\begin{array}{l}\text { она ходила } \\
\left(3 K_{2}, \text { с. } 6\right)\end{array}$ \\
\hline 5 & $2 \omega$ & сиy2u & $\begin{array}{c}\text { слуги } \\
\left(3 K_{2}, \text { с. } 6\right)\end{array}$ \\
\hline 6 & you & & $\begin{array}{c}\text { разговаривать } \\
\left(3 K_{2}, \text { с. } 6\right)\end{array}$ \\
\hline
\end{tabular}

Табл. 5. Варианты написания строчной буквы «и» в $3 K_{2}$

Неверно прочитано окончание слова «достижения» в записи со с. $493 K_{2}$ : "развитія личности и достиженія окончательной иъпли»; ср.: «развития личности и достижению окончательной цели» [ЛН, т. 83: 174]. Как видим, в рукописи буква «я» не прописана четко, кроме того, чернила немного размыты, что затруднило чтение данного слова. Если учитывать контекст (см. Илл. 12), то становится очевидным, что требуется форма Род. п. ед. ч., как и в слове «развития», так как в тексте однородные дополнения: «Это на землть невозможно, ибо противуртчить Закону [личности, т. е.] развитія личности и достиженія окончательной ильли, которымъ связанб человпкб».

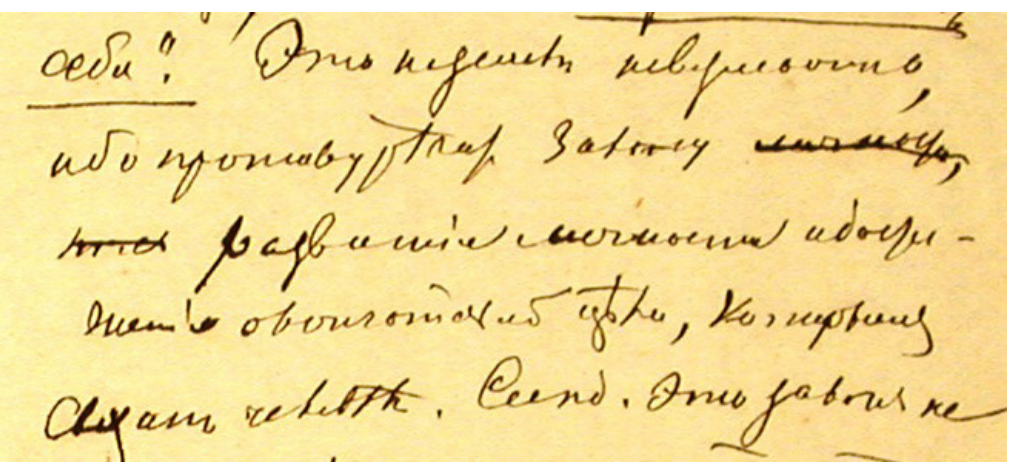

Илл. 12. Фрагмент с. $493 K_{2}$ 
На с. 52 имеется набросок: «Мы будемъ - лица, не переставая сливаться со вспмб, не посягая и не женясь, и въ различныхт разрядахт; [ибо въ д] (въ дому отия моего обител[b]\{u\} многи суть» (см. Илл. 13). В первой публикации текст был прочитан с неточностями: «Мы будем жить, не переставая сливаться со всем, не посягая и не женясь, и в различных разрядах; [обов] (в дому отца моего обители многа суть» [ЛН, т. 83: 174].

Это часть записи от 16 апреля 1864 г., сделанной Достоевским на следующий день после смерти первой жены Марии Дмитриевны и неоднократно привлекавшей внимание исследователей. Запись, как известно, переросла в конспект статьи «Социализм и христианство», разработанный позже в записной тетради 1864-1865 гг. (РГАЛИ. Ф. 212.1.4)․․․ Ошибка чтения устанавливается благодаря тому, что Достоевский использует в данном случае прямую цитату из Евангелия от Иоанна, ср.: «...в дому Отца Моего обители многи суть: аще ли же ни, рекл бых вам: иду уготовати место вам: и аще уготовлю место вам, паки прииду и поиму вы к Себе, да идеже есмь Аз, и вы будете» (Ин. 14: 2-3).

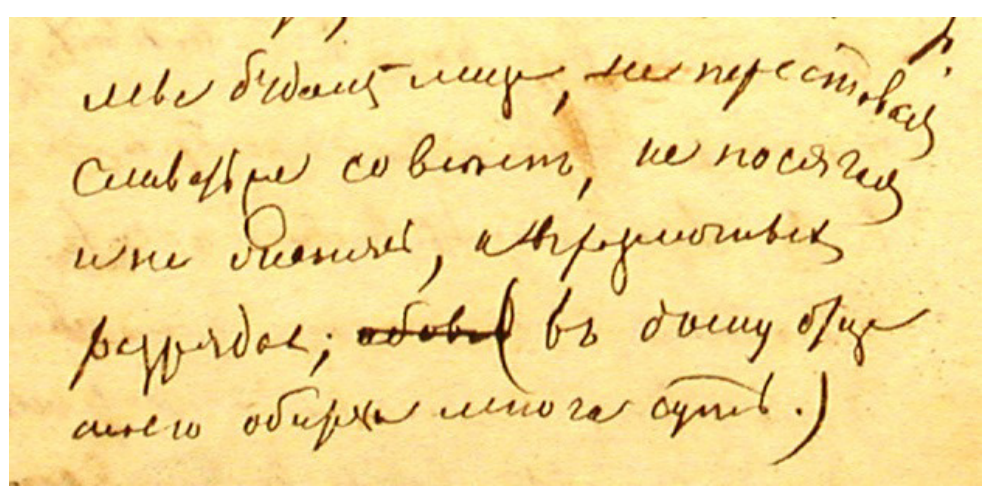

Илл. 13. Фрагмент с. $523 K_{2}$

В данном отрывке в начале предложения неверно прочитано слово «лица» - как «жить». В автографе нет графических признаков этого слова. Буква «ц» в почерке Достоевского пишется почти всегда одинаково: в центральной части напоминает «и», но заканчивается нижней петлей различной длины и ширины. Петля иногда может быть не прописана. Приведем варианты написания строчной буквы «ц» в данной ЗК (см. Табл. 6).

\begin{tabular}{|c|c|c|c|}
\hline № & $\begin{array}{c}\text { Фото } \\
\text { буквы }\end{array}$ & Фото контекста & Текст \\
\hline \multirow{2}{*}{1} & cf & Clnary i to & $\begin{array}{l}\text { станцію } \\
\left(3 K_{2}, \text { c. } 3\right) \\
\text { карандаш }\end{array}$ \\
\hline
\end{tabular}




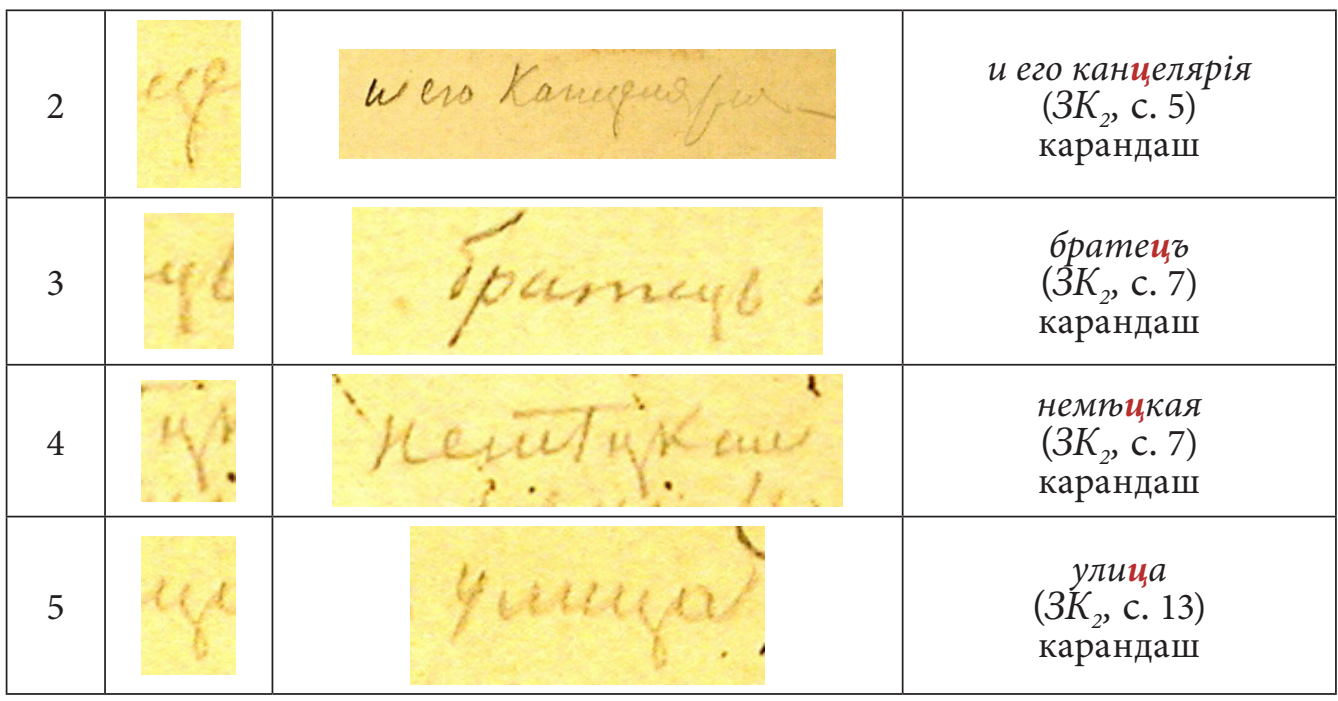

Табл. 6. Варианты написания строчной буквы «ц» в $3 K_{2}$

Буква «т», наоборот, имеет два основных варианта написания: с тремя вертикальными штрихами и с надстрочным штрихом или без него, а также с верхней и нижней выносными линиями, с петлеобразными штрихами или без них (см. Табл. 7).

\begin{tabular}{|c|c|c|c|}
\hline № & $\begin{array}{c}\text { Фото } \\
\text { буквы }\end{array}$ & Фото контекста & Текст \\
\hline 1 & & & $\begin{array}{c}\text { Тракmу } \\
\left(3 K_{2}, \text { с. 3) }\right. \\
\text { карандаш }\end{array}$ \\
\hline 2 & & & $\begin{array}{c}\text { станиію } \\
\left(3 K_{2}, \text { с. 3) }\right. \\
\text { карандаш }\end{array}$ \\
\hline 3 & & On & $\begin{array}{l}\text { Статья } \\
\left(3 K_{2}, \text { с. } 6\right)\end{array}$ \\
\hline 4 & $+f_{2}$ & Punfers & $\begin{array}{l}\text { Статья } \\
\left(3 K_{2}, \text { с. } 6\right)\end{array}$ \\
\hline 5 & mber & hank & $\begin{array}{c}\text { Проклятый } \\
\left(3 K_{2}, \text { с. 6) }\right.\end{array}$ \\
\hline 6 & cons. & Yucmblem & $\begin{array}{c}\text { Умственныя } \\
\left(3 K_{2}, \text { с. } 6\right)\end{array}$ \\
\hline 7 & nevi & & $\begin{array}{c}\text { потому } \\
\left(3 K_{2}, \text { с. } 6\right)\end{array}$ \\
\hline
\end{tabular}




\begin{tabular}{|c|c|c|c|}
\hline 8 & the & Pres & $\begin{array}{c}\text { что } \\
\left(3 K_{2}, \text { c. 6) }\right.\end{array}$ \\
\hline 9 & ene & 'sonaeneberens' & $\begin{array}{c}\text { монастьрямб } \\
\left(3 K_{2}, \text { с. 6) }\right.\end{array}$ \\
\hline 10 & he & moveblo & $\begin{array}{c}\text { только } \\
\left(3 K_{2}, \text { с. } 6\right)\end{array}$ \\
\hline 11 & $1 / 8$ & mory/s & $\begin{array}{c}\text { могуmв } \\
\left(3 K_{2}, \text { c. 6) }\right.\end{array}$ \\
\hline 12 & net & & $\begin{array}{c}\text { разговаривать } \\
\left(3 K_{2}, \text { с. } 6\right)\end{array}$ \\
\hline
\end{tabular}

Табл. 7. Варианты написания буквы «т» в $3 K_{2}$

В Д30 неточно прочитан набросок на с. 23: «Раньше не оставит бога» (Д30; 20: 171). В ЛН [т. 83: 180] прочтение верное: «Раньше не оставите Бога» (см. Илл. 14).

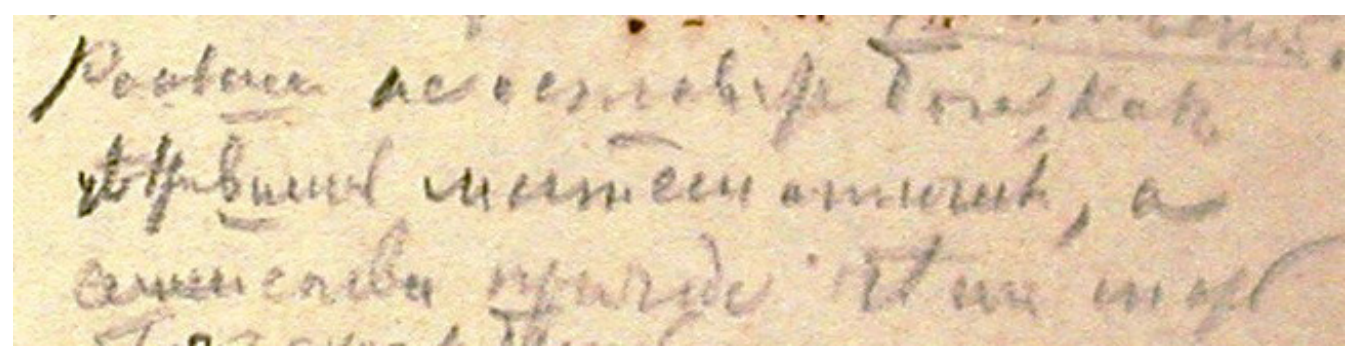

Илл. 14. Фрагмент с. $233 K_{2}$

Для аргументации этого чтения рассмотрим варианты написания «ъ» на концах слов в $3 K_{2}$ (см. Табл. 8).

\begin{tabular}{|c|c|c|c|}
\hline № & Фото буквы & Фото контекста & Текст \\
\hline 1 & 6. & biलme & $\begin{array}{l}\text { выҺьзды } \\
\left(3 K_{2}, \text { c. } 1\right)\end{array}$ \\
\hline 2 & 3 & ug clloukfor & $\begin{array}{c}\text { uзz Moсквbl } \\
\left(3 K_{2}, \text { c. } 1\right)\end{array}$ \\
\hline 3 & $K_{\ell}$ & Cobjeшнниек & $\begin{array}{l}\text { Современникв } \\
\left(3 K_{2}, \text { с. } 6\right)\end{array}$ \\
\hline 4 & éns' & nouarneberens' & $\begin{array}{l}\text { монастырямб } \\
\left(3 K_{2}, \text { с. } 6\right)\end{array}$ \\
\hline 5 & ato & hato & $\begin{array}{c}\text { Тaкъ } \\
\left(3 K_{2}, \text { с. } 6\right)\end{array}$ \\
\hline
\end{tabular}




\begin{tabular}{|c|c|c|c|}
\hline 6 & $1 / 8$ & mory/z & $\begin{array}{c}\text { Morymz } \\
\left(3 K_{2}, \text { с. } 6\right)\end{array}$ \\
\hline 7 & $u$ & $\begin{array}{l}\text { peseopas } \\
\text { envadak }\end{array}$ & $\begin{array}{c}\text { Госnодахв } \\
\left(3 K_{2}, \text { с. 6) }\right.\end{array}$ \\
\hline
\end{tabular}

Табл. 8. Варианты написания буквы «ъ» в $3 K_{2}$

Как видим, ни один из приведенных вариантов не подтверждает чтение Д30 (оставитъ) - последняя буква более похожа на «е» с концевым хвостиком и соединительным штрихом от «т». Рассмотрим также эту фразу в более широком контексте:

«Соиіалисть хотять переродить человпка<,> освободить его, представи<ть> его безъ Бога и безъ семейства. Они заключають, что измпнивъ насильно экономическій бытъ его иъпли достигнутъ. Но человпкъ [не] измпнится [пр] не оть внтьшних причинб, а не иначе какъ оть перемтнь нравственной. Раньше не оставите Бога, какъ увтривиись математически, а семейства прежде чюмъ мать [будеть] \{не захочеть быть\} матерью, а человпкъ не захочеть обратить любовь въ клубничку. Можно-ли достигнуть этого оружіемъ. И какъ смпть сказать заранп, прежде опыта, что въ этомъ спасеніе? И это рискуя вспмъ человпчествомъ. Западная дребеденъ.»

При использовании формы ед. ч. («оставит») получается, что человек (и человеческая природа в целом) сам стремится, «уверившись математически», оставить веру в Бога. Однако мысль Достоевского глубже: он обвиняет в этом социалистическое учение и социалистов и задается риторическим вопросом, возможно ли достигнуть такой перемены в человеке оружием, то есть насильно? Ответ очевиден: нет. Прочтение ЛН «не оставите», таким образом, подтверждают не только графические особенности написания слова, но и содержание высказывания.

Отметим еще несколько ошибок чтения, которые искажают смысл записей. Так, на с. 6 записано: «Современникъ Іюнь». В Д30 запись прочитана как «"Современник”. Июль» (Д30; 20: 171). См. Илл. 15.

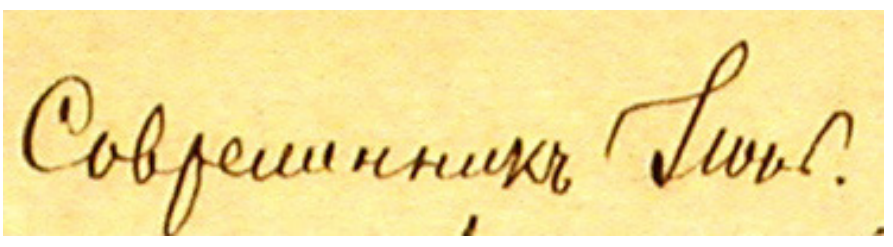

Илл. 15. Фрагмент с. $63 K_{2}$ 
Сравним написание строчных букв «л» и «н» в почерке Достоевского. Как было установлено на примере $3 K_{1}$, вариантов написания буквы «л» четыре: классический; с верхним выносным штрихом - с петлей или без нее; в составе лигатуры «ль». Ср. написание данной буквы в $3 K_{2}$ (Табл. 2). Буква «н» имеет следующие варианты написания: традиционный, с двумя вертикальными штрихами и горизонтальным посередине, и вариант скорописи, как в нашем случае, когда она становится похожа на «и» (см. Табл. 9). В приведенном примере имеется в виду именно июнь: в 6-м номере «Современника» за 1864 г. вышла анонимная рецензия «Новый роман автора “Проклятого”» на книгу аббата ${ }^{* * *}$ «La Religieuse» («Монахиня»), которую и упоминает здесь Достоевский (см.: Д30; 20: 362).

\begin{tabular}{|c|c|c|c|}
\hline № & $\begin{array}{c}\text { Фото } \\
\text { буквы }\end{array}$ & Фото контекста & Текст \\
\hline 1 & & & $\begin{array}{c}\text { губерн }<\text { iu > } \\
\left(3 K_{2}, \text { с. 3) }\right. \\
\text { карандаш }\end{array}$ \\
\hline 2 & & & $\begin{array}{c}\text { нa } \\
\left(3 K_{2}, \text { c. 3) }\right. \\
\text { карандаш }\end{array}$ \\
\hline 3 & 1 & & $\begin{array}{l}\text { станцію } \\
\left(3 K_{2}, \text { с. 3) }\right. \\
\text { карандаш }\end{array}$ \\
\hline 4 & & & $\begin{array}{c}\text { станцію Теплинку } \\
\left(3 K_{2}, \text { с. } 3\right) \\
\text { карандаш }\end{array}$ \\
\hline 5 & 160 & & $\begin{array}{c}\text { Степановнг } \\
\left(3 K_{2}, \text { с. 3) }\right. \\
\text { карандаш }\end{array}$ \\
\hline 6 & & & $\begin{array}{l}\text { Соханской } \\
\left(3 K_{2}, \text { с. 3) }\right. \\
\text { карандаш }\end{array}$ \\
\hline 7 & Hete & Cobfenнтнеке & $\begin{array}{c}\text { Современникъ } \\
\left(3 K_{2}, \text { с. } 6\right)\end{array}$ \\
\hline 8 & w? & n & $\begin{array}{c}\text { Iюнь } \\
\left(3 K_{2}, \text { c. } 6\right)\end{array}$ \\
\hline
\end{tabular}




\begin{tabular}{|c|c|c|c|}
\hline 9 & ret & ofacrant & $\begin{array}{l}\text { о романпь } \\
\left(3 K_{2}, \text { с. } 6\right)\end{array}$ \\
\hline 10 & tete & 1) cusbenet we & $\begin{array}{c}\text { Умственныя } \\
\left(3 K_{2}, \text { с. } 6\right)\end{array}$ \\
\hline 11 & E. & onventer & $\begin{array}{c}\text { она ходила } \\
\left(3 K_{2}, \text { с. } 6\right)\end{array}$ \\
\hline 12 & Ha & sura 'nebeperens' & $\begin{array}{c}\text { монастьцямь } \\
\left(3 K_{2}, \text { с. } 6\right)\end{array}$ \\
\hline
\end{tabular}

Табл. 9. Варианты написания буквы «н» в $3 K_{2}$

Ошибка возникла и при расшифровке записи на с. 145. Читаем: «31) Іюля дано $3^{\infty}$ » вместо: «31) Коле дано 3 р.» [ЛН, т. 83: 183]. См. Илл. 16. В подобных случаях (записи для памяти долгов, расчеты) «подсказывающий» контекст обычно минимален или вообще отсутствует, и главным критерием правильности чтения записи становится графика.

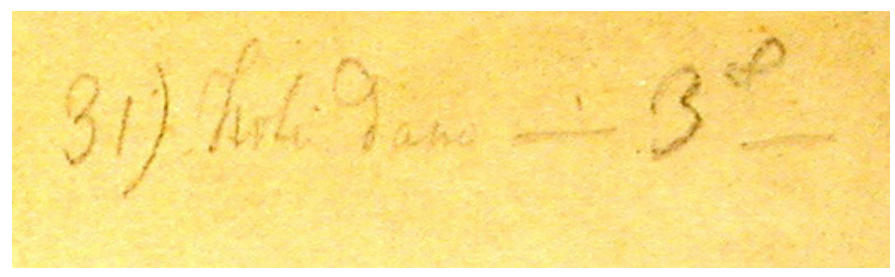

Илл. 16. Фрагмент с. $1453 K_{2}$

В данном случае не читается «Ђ» на конце слова, который имеет обычное написание, характерное для скорописи Достоевского, но может писаться с верхним выносным штрихом (см. Табл. 10).

\begin{tabular}{|c|c|c|c|}
\hline № & $\begin{array}{c}\text { Фото } \\
\text { буквы }\end{array}$ & Фото контекста & Текст \\
\hline 1 & 17 & & $\begin{array}{c}16 \text { Апрпляя } \\
\left(3 K_{2}, \text { с. } 1\right)\end{array}$ \\
\hline 2 & 91 & & $\begin{array}{c}\text { Bblnb } 3 d z \\
\left(3 K_{2}, \text { c. } 1\right)\end{array}$ \\
\hline 3 & & & $\begin{array}{c}\text { Надежди } \\
\left(3 K_{2}, \text { с. } 3\right) \\
\text { карандаш }\end{array}$ \\
\hline
\end{tabular}




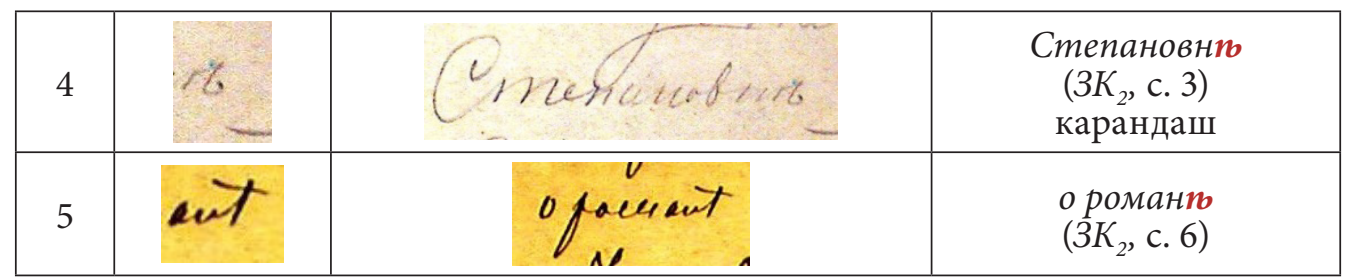

Табл. 10. Варианты написания буквы «Ђ» в $3 K_{2}$

Похожие смысловые ошибки возникли в первой публикации на с. 14 и 15 - там, где Достоевский ведет подсчет долгов по изданию журнала: дважды ошибочно прочитано «было» [ЛН, т. 83: 177-178] вместо верного «около». См. Илл. 17.

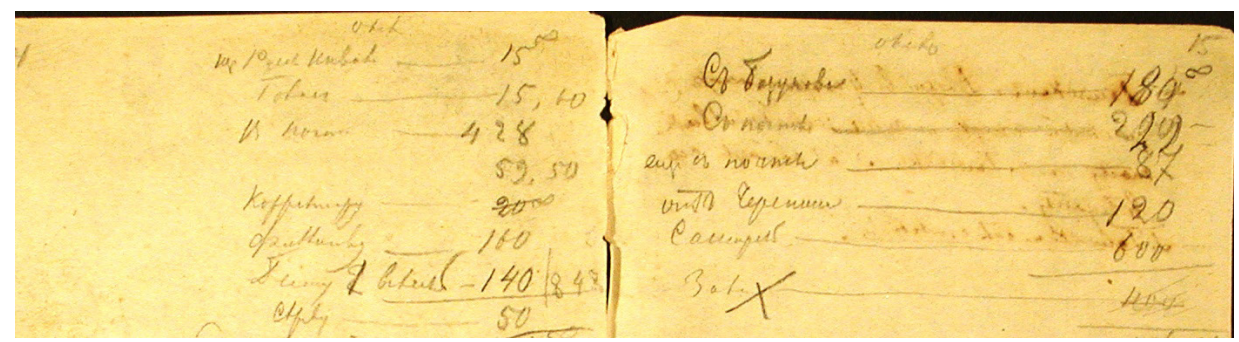

Илл. 17. Фрагмент с. 14-15 3К

Прописная «К» имеет в почерке Достоевского все характерные признаки данной буквы, а вот «I» зачастую смешивается с латинской «L» (см. Табл. 11 и Илл. 18).

\begin{tabular}{|c|c|c|c|}
\hline № & $\begin{array}{c}\text { Фото } \\
\text { буквы }\end{array}$ & Фото контекста & Текст \\
\hline 1 & & $10, i s$ & $\begin{array}{c}10 \text { Іюля } \\
\left(3 K_{2}, \text { с. } 1\right)\end{array}$ \\
\hline 2 & Stor & Sers & $\begin{array}{c}\text { IюHb } \\
\left(3 K_{2}, \mathrm{C} .6\right)\end{array}$ \\
\hline
\end{tabular}

Табл. 11. Варианты написания буквы «І» в $3 K_{2}$

Илл. 18. Фрагмент с. $93 K_{2}$ 
Среди других ошибок чтения не просто из-за одной неправильно прочитанной буквы, а из-за того, что неверно угадан рисунок слова в целом, можно перечислить следующие:

1) Запись со с. 18 читаем как: «П<етрашевс>кій уже предупрежденъ младиимъ что этотъ доносиикъ» вместо: «П<етрашевс>кий уже предупрежден младшим, что этот донесет» [ЛН, т. 83: 179]; (Д30; 1: 435).

В данном случае ошибка «донесет» возникла из-за того, что букву «ч» в слове «доносчикъ» в конце предложения Достоевский прописал с неотчетливым верхним изгибом (см. Илл. 19).

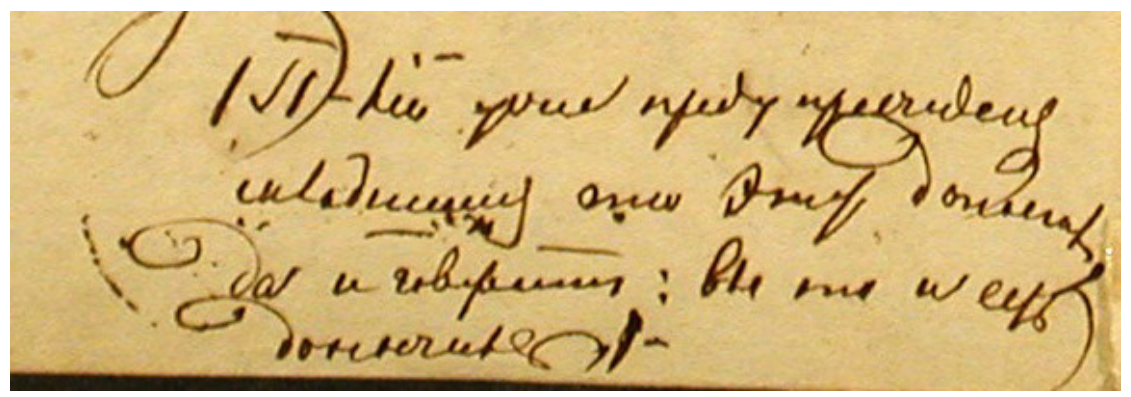

Илл. 19. Фрагмент с. $183 K_{2}$

Кроме того, буква «К» с высоким выносным штрихом напоминает здесь «т», которая писалась не только традиционно (с тремя вертикальными штрихами, соединенными дугообразными элементами), но и с верхней выносной линией с изгибом, петлеобразным штрихом или без него (см. Табл. 7). Это - смешение букв - также могло быть условием для неверного чтения текста. Тем не менее, для прочтения «донесет» в анализируемой записи слишком много букв, а буква «к» вполне узнаваема, ср. с другими примерами (см. Табл. 12).

\begin{tabular}{|c|c|c|c|}
\hline № & $\begin{array}{c}\text { Фото } \\
\text { буквы }\end{array}$ & Фото контекста & Текст \\
\hline 1 & $x$ & agr chouxch: & $\begin{array}{c}\text { изб Москвы } \\
\left(3 K_{2}, \text { c. } 1\right)\end{array}$ \\
\hline 2 & ha & & $\begin{array}{c}\text { Харьковской } \\
\left(3 K_{2}, \text { с. 3) }\right. \\
\text { карандаш }\end{array}$ \\
\hline 3 & & & $\begin{array}{c}\text { Харьковской } \\
\left(3 K_{2}, \text { с. } 3\right) \\
\text { карандаш }\end{array}$ \\
\hline
\end{tabular}




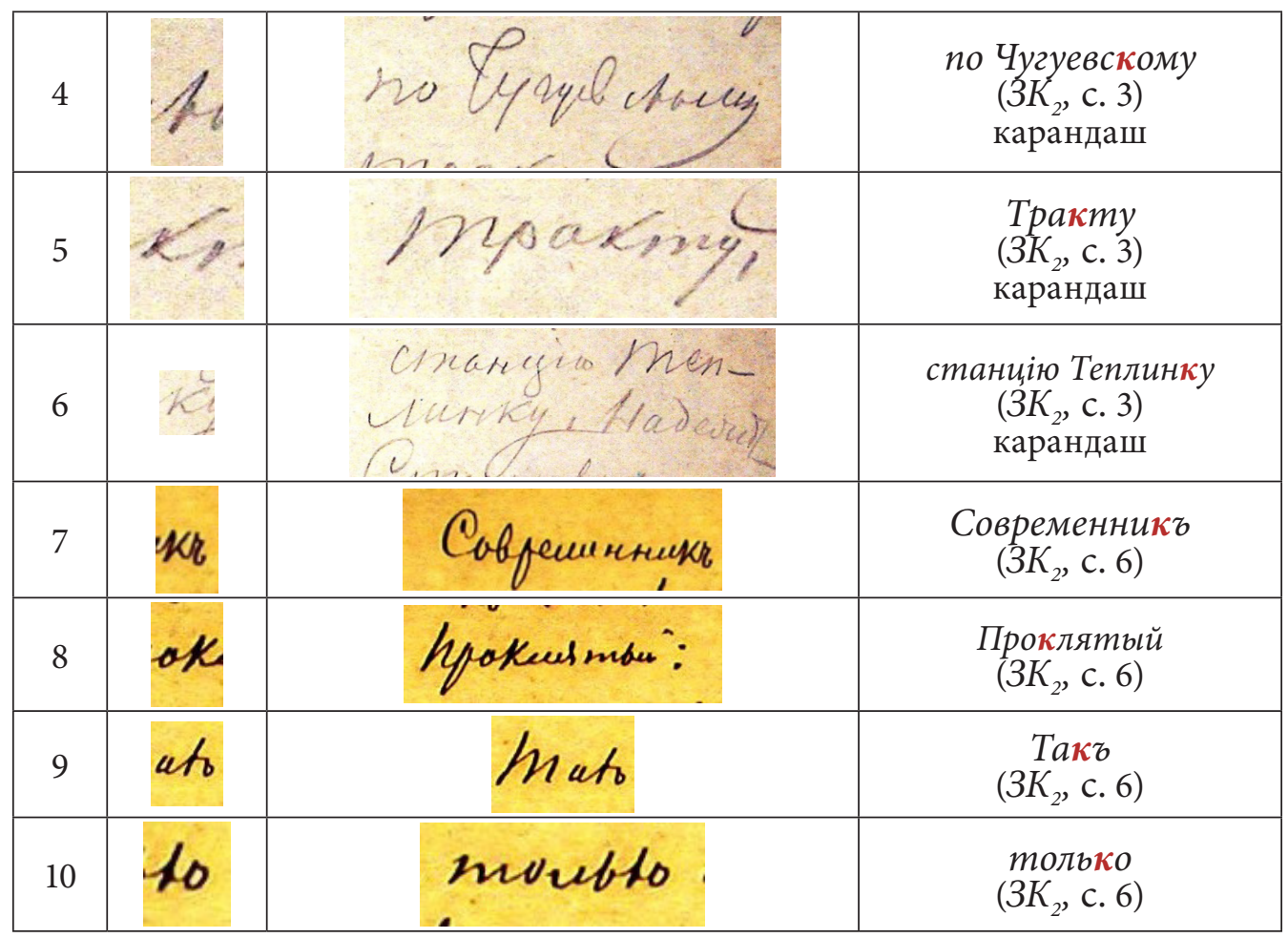

Табл. 12. Варианты написания буквы «К» в $3 K_{2}$

2) Запись со с. 65 читаем как: «Освобождая въ Польшпь крестьянъ и удпляя имъ землю, Россія ужъ удюлила Польшп свою мысль, привила ей свой характерб» вместо: «Освобождая в Польше крестьян и уделяя им землю, Россия тем уделила Польше свою мысль, привила ей свой характер» [ЛН, т. 83: 176]. См. Илл. 20.

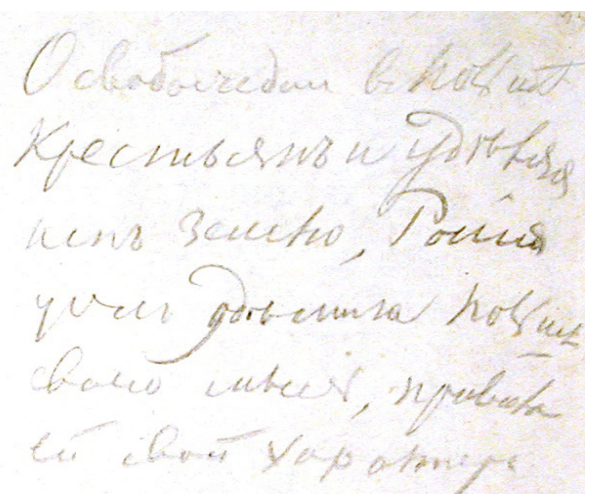

Илл. 20. Фрагмент с. $653 K_{2}$ 
Об особенностях написания строчной буквы «ж» мы уже говорили выше (см. Илл. 8): у этой буквы очень узнаваемое начало - широкий отстоящий от последующих штрихов завиток (см. Табл. 13).

\begin{tabular}{|c|c|c|c|}
\hline № & $\begin{array}{c}\text { Фото } \\
\text { буквы }\end{array}$ & Фото контекста & Текст \\
\hline 1 & 1 & & $\begin{array}{l}\text { Надеждь } \\
\left(3 K_{2}, \text { с. 3) }\right. \\
\text { карандаш }\end{array}$ \\
\hline 2 & 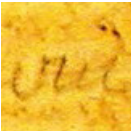 & & $\begin{array}{c}\text { Бажанова } \\
\left(3 K_{2}, \text { с. 5) }\right. \\
\text { карандаш }\end{array}$ \\
\hline 3 & $\mathrm{Nu}$ & yonabe - & $\begin{array}{l}\text { ужсасньй } \\
\left(3 K_{2}, \text { с. } 16\right)\end{array}$ \\
\hline
\end{tabular}

Табл. 13. Варианты написания строчной буквы «ж» в $3 K_{2}$

Ср. написание слова «уже» в $3 K_{2}$ :
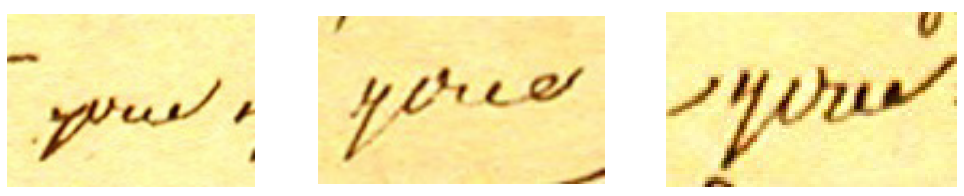

Илл. 21. Фрагменты с. 18, 45 и $493 K_{2}$

3) Запись со с. 154 читаем как: «Гамаліилъ. Разборъ словъ Гамаліила, свобода слова» вместо: «Гамалиил. Разбор слов Гамалиила, свобода мы<сли>» [ЛН, т. 83: 172].

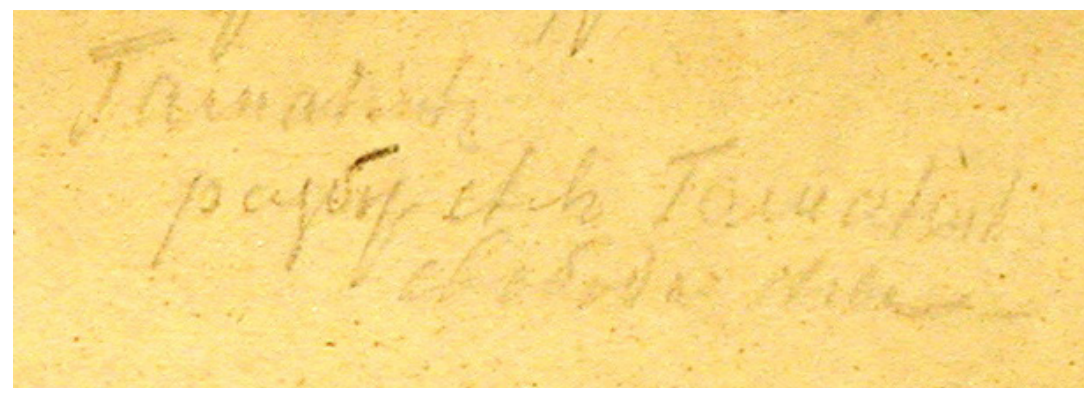

Илл. 22. Фрагмент с. $1543 K_{2}$

В Д30 слово прочитано правильно, кроме того, дан комментарий: «Гамалиил <...> призвал “мужей израильских” отпустить из темницы апостолов. 
Внимание Достоевского привлекли слова Гамалиила, призывающего членов синедриона не карать апостолов за “слово”, обращенное к народу» (Д30; 20: 362). Ошибка чтения в ЛН возникла вследствие того, что в почерке Достоевского, как говорилось выше, буква «л» может писаться с верхней выносной высокой линией (см. Табл. 2).

4) Запись со с. 137 читаем как: «Но мы совершенно не знаемъ и не умпемъ до сихъ порь что хвалить на Руси» вместо: «Но мы совершенно не знаем и не имеем до сих пор что хвалить на Руси» [ЛН, т. 83: 172].

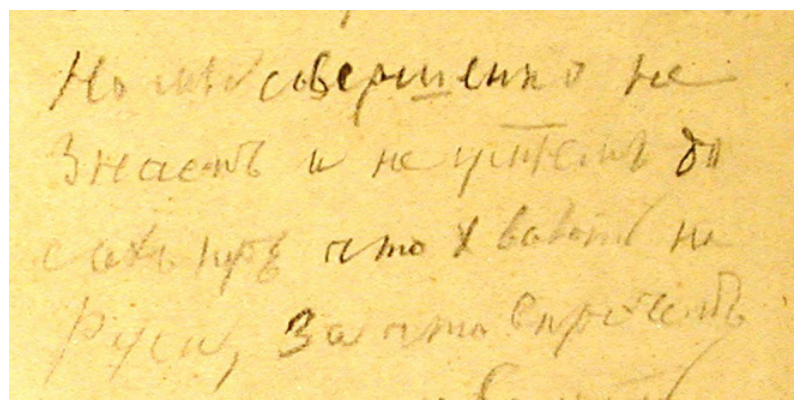

Илл. 23. Фрагмент с. $1373 K_{2}$

В данном случае строчная буква «у» читается более или менее четко. В почерке Достоевского она может оставаться в пределах строки (короткое «у») или выходить за ее границы. В примере представлен усредненный вариант, ср. написание буквы «у» в $3 K_{2}$ (см. Табл. 14).

\begin{tabular}{|c|c|c|c|}
\hline № & Фото буквы & Фото контекста & Текст \\
\hline 1 & 2 & & $\begin{array}{c}\text { губернн<iu> } \\
\left(3 K_{2}, \text { с. 3) }\right. \\
\text { карандаш }\end{array}$ \\
\hline 2 & & & $\begin{array}{c}\text { по Чугуевскому } \\
\left(3 K_{2}, \text { с. 3) }\right. \\
\text { карандаш }\end{array}$ \\
\hline 3 & & & $\begin{array}{c}\text { по Чугуевскому } \\
\left(3 K_{2}, \text { с. 3) }\right. \\
\text { карандаш }\end{array}$ \\
\hline 4 & & & $\begin{array}{c}\text { Тракту } \\
\left(3 K_{2}, \text { c. } 3\right) \\
\text { карандаш }\end{array}$ \\
\hline
\end{tabular}




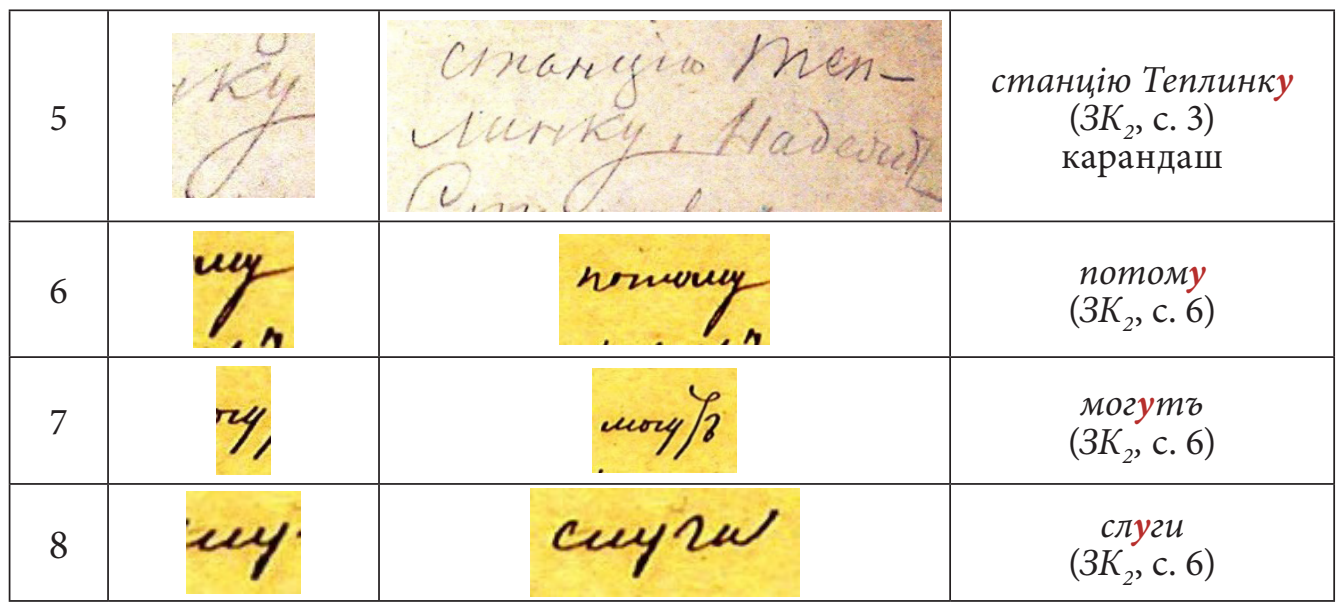

Табл. 14. Варианты написания строчной буквы «у» в $3 K_{2}$

5) Запись со с. 58 читаем как: «ни къ чему не приведуть и на ихъ же гла̀вы обрушатся» вместо: «ни к чему не приведут и на их же головы обрушатся» [ЛН, т. 83: 176], (Д30; 20: 175)

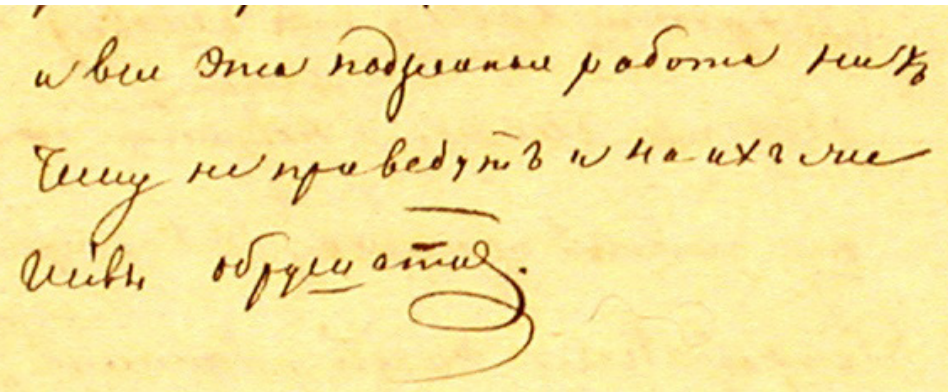

Илл. 24. Фрагмент с. $583 K_{2}$

Как видим, в рукописи нет полногласия, к тому же проставлено ударение над гласной «а». Скорее всего, в публикации рукописи редакторы решили использовать более современный вариант слова.

В $3 K_{3}$, которая заполнялась в 1864-1865 гг., тоже есть записи, неверно прочитанные публикаторами.

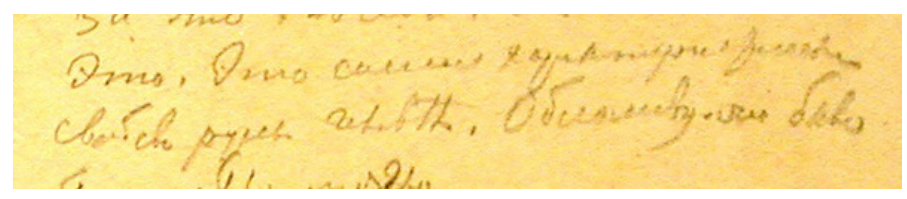

Илл. 25. Фрагмент с. $43 K_{3}$ 
Запись со с. 4 читаем как: «Это самое характеристическое свойс $<m>$ во русск<аго> человпка» вместо: «Это самое характеристичное свойство русского человека» [ЛН, т. 83: 284]. См. Илл. 25.

В данном случае свою роль играет инерция восприятия - при чтении публикатор выбирает более привычный вариант. Кроме того, имеет значение начертание букв. В почерке писателя буква «е» имеет традиционное и узнаваемое написание, но в некоторых случаях в беглом почерке может сводиться графически к точке и почти не проявляться в слове. Это же характерно для других гласных букв («а», «о», «И»). См. варианты написания строчной буквы «е» в Табл. 15.

\begin{tabular}{|c|c|c|c|}
\hline № & $\begin{array}{c}\text { Фото } \\
\text { буквы }\end{array}$ & Фото контекста & Текст \\
\hline 1 & Cos & & $\begin{array}{c}\text { губерн }<i u> \\
\left(3 K_{2}, \text { с. 3) }\right. \\
\text { карандаш }\end{array}$ \\
\hline 2 & el & ely & $\begin{array}{c}\text { по Чугуевскому } \\
\left(3 K_{2}, \text { с. 3) }\right. \\
\text { карандаш }\end{array}$ \\
\hline 3 & e & $\begin{array}{l}\text { jicon- } \\
\text { Hadewel }\end{array}$ & $\begin{array}{c}\text { станиію Теплинка } \\
\left(3 K_{2}, \text { с. } 3\right) \\
\text { карандаш }\end{array}$ \\
\hline 4 & $(e)$ & & $\begin{array}{l}\text { Надеждю } \\
\left(3 K_{2}, \text { с. } 3\right) \\
\text { карандаш }\end{array}$ \\
\hline 5 & $e$ & Cobjenнтиек & $\begin{array}{l}\text { Современникъ } \\
\left(3 K_{2}, \text { с. } 6\right)\end{array}$ \\
\hline 6 & us & 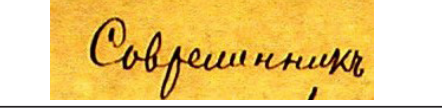 & $\begin{array}{c}\text { Современникъ } \\
\left(3 K_{2}, \text { с. } 6\right)\end{array}$ \\
\hline 7 & be & Yucnobenet we & $\begin{array}{c}\text { УМственныя }_{\text {Мст }} \\
\left(3 K_{2}, \text { с. } 6\right)\end{array}$ \\
\hline 8 & Pry & Puefers & $\begin{array}{c}\text { Teрезы } \\
\left(3 K_{2}, \text { c. } 6\right)\end{array}$ \\
\hline
\end{tabular}

Табл. 15. Варианты написания строчной буквы «е» в $3 K_{2}$

Ср. также написание «-ческое» в названии «Политическое обозриніе» в $3 K_{3}$. Так же недописано окончание слова, буква «к» с высоким вертикальным штрихом. 


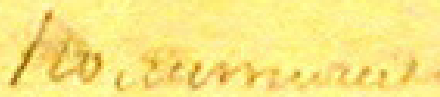

Илл. 26. Фрагмент с. $23 K_{3}$

На с. 12 3К з читаем: «Послушно вамъ дютей рождать» вместо: «Послушно вам детей рожать» [ЛН, т. 83: 285]. В публикации ошибка набора, так как строчная буква «д» в почерке писателя узнаваема, особенностью является большой завиток, хотя буква может иметь и другие начертания (см. Илл. 27 и Табл. 16).

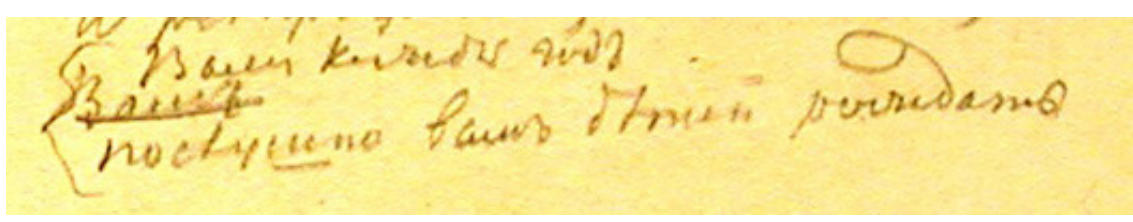

Илл. 27. Фрагмент с. $123 K_{3}$

\begin{tabular}{|c|c|c|c|}
\hline № & Фото буквы & Фото контекста & Текст \\
\hline 1 & mil & li & $\begin{array}{c}\text { выҺьздъ } \\
\left(3 K_{2}, \text { c. } 1\right)\end{array}$ \\
\hline 2 & $15 \times 2$ & & $\begin{array}{l}\text { Надеждн } \\
\left(3 K_{2}, \text { с. } 3\right) \\
\text { карандаш }\end{array}$ \\
\hline 3 & & & $\begin{array}{c}\text { Надеждл } \\
\left(3 K_{2}, \text { с. } 3\right) \\
\text { карандаш }\end{array}$ \\
\hline 4 & wyon & owewenter & $\begin{array}{c}\text { она ходила } \\
\left(3 K_{2}, \text { с. } 6\right)\end{array}$ \\
\hline 5 & Denada. & $\begin{array}{l}\text { peseras } \\
\text { encuarak }\end{array}$ & $\begin{array}{c}\text { Господахъ } \\
\left(3 K_{2}, \text { c. } 6\right)\end{array}$ \\
\hline
\end{tabular}

Табл. 16. Варианты написания строчной буквы «д» в $3 K_{2}$

На с. 29 ЗК читаем: «Передовая статья въ Генвариъ вместо: «Передовые статьи в генваре» [ЛН, т. 83: 286], (Д30; 20: 204). 


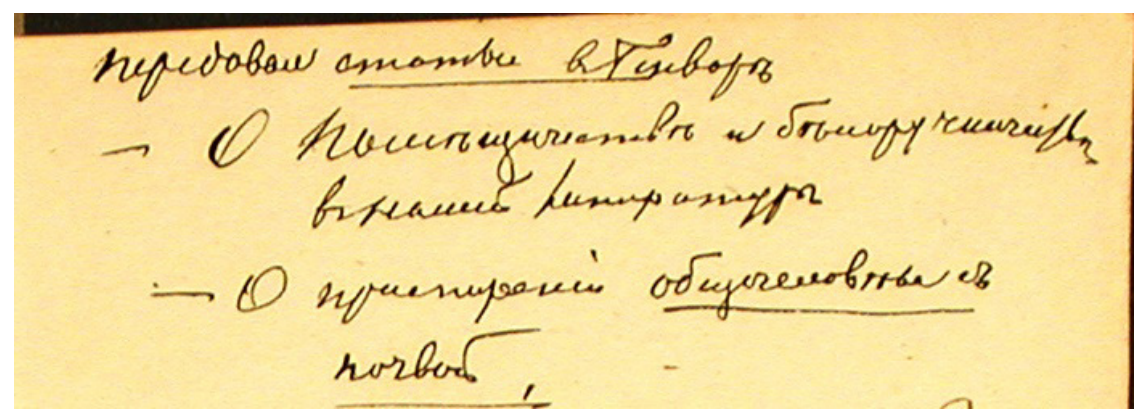

Илл. 28. Фрагмент с. $293 K_{3}$

Несмотря на то, что на данной странице Достоевский записал примерные названия двух предполагаемых статей («О помпщиччестви и бюлоручничестви въ нашей литературп» и «О примиреніи общечеловюка съ почвой»), так и не опубликованных, в заголовок наброска вынесена форма ед. ч. - «передовая статья», что, возможно, связано с изменением первоначального замысла (задумана одна статья, записаны два названия).

\section{Записи издательского характера, расчеты, записи долгов, записи для памяти в 3T 1864-1865 гг. (проблемы публикации)}

История публикации записных книжек и тетрадей Достоевского насчитывает уже более 135 лет. Известны различные подходы к принципам публикации, отбора материала, к целям, поставленным перед исследователями и издателями рукописного текста.

В первом посмертном ПСС1883 $3^{4}$ и в некоторых журналах были напечатаны только немногочисленные выдержки, в основном, из последней записной тетради 1880-1881 гг.

В полном объеме записные книжки и тетради Достоевского стали доступны для исследователей творчества писателя только в 1920-е гг. Внимание исследователей привлекли прежде всего записи литературного характера. Рукописи рассматривались как источник «ценнейших материалов творческой лаборатории писателя», дающий возможность в полном объеме «изучить историю создания его $<\ldots>$ романов, $<\ldots>$ повестей и публицистических статей. <...> Такой подход и закономерен и безусловно плодотворен» [Розенблюм, 1971: 13]. Именно в свете такого подхода в 1920-е 1970 -е гг. ${ }^{5}$ были подготовлены «публикации, специально посвященные творческой истории [определенного] романа» [От редакции, 1971: 6], для чего из единого корпуса текстов записных книжек и тетрадей извлекались только записи, относящиеся к истории избранного произведения ${ }^{6}$.

Уже на ранней стадии изучения рукописей Достоевского в публикации Е. Н. Коншиной были обозначены слабые места подобного принципа воспроизведения текстов записных тетрадей: «ограничиваясь извлечениями 
текста, относящегося к какому-либо из произведений автора», мы получаем «редакторско-препарированный текст», но при этом разрываем «единый документ» с «живым сочетанием разнообразных заметок» и рискуем совершить ошибку, отнеся замысел, легший в основу сразу нескольких произведений, только к одному [Коншина: 13]. При подготовке к изданию 4-х записных тетрадей Достоевского (1935) она следовала другому принципу - сохранению целостности документа «во всей своей полноте и даже пестроте», считая его более плодотворным и способным осветить «разнообразнейшие проблемы, связанные с творчеством, жизнью и личностью автора» [Коншина: 13]. Позднее Л. М. Розенблюм, отметив, что ориентироваться в разнородном и многообразном материале сложно [Розенблюм, 1965: 53], также говорила о целостном подходе к тексту во вступительной статье к тому 83 «Литературного наследства» (1971), содержащему публикацию записных книжек и тетрадей Достоевского: рассматривая «рабочие тетради» как своеобразные творческие дневники писателя, «где работа над конкретным произведением представляется частью духовной жизни автора в высшем ее проявлении», она указывала на важность такого аспекта их изучения [Розенблюм, 1971: 13]. Впоследствии ею же была высказана мысль о том, что в изданиях, построенных на принципе «тематического разделения материалов записных книжек Достоевского», «записи лишаются той естественной среды, в которой они возникли и которая небезразлична для их понимания» [Розенблюм, 1997: 92].

Однако в ХХ в. эти принципы воспроизведения текста записных книжек и тетрадей как единого документа остались неосуществленными. Исходная целостность данных рукописных материалов, после революции разделенных и находящихся на хранении в разных архивных собраниях, в первых печатных их публикациях восстановлена не была. На протяжении всего XX столетия проблема публикации записных тетрадей Достоевского, связанная с изучением особенностей и реконструкцией творческого процесса писателя, привлекала внимание исследователей, оставшись актуальной и в постсоветское время. В наши дни многолетние исследования рукописей Достоевского, накопленный за это время опыт, а также появившиеся в последние десятилетия «возможности электронного воспроизведения рукописного текста с максимально полным отражением его особенностей и с использованием специфики информационной интернет-среды» позволили сформировать новый подход к публикации рукописей Достоевского, приоритетным в котором «является рассмотрение авторского текста как целого и записных тетрадей писателя как идейно-эстетической целостности и одновременно - исторического документа, содержащего как творческие замыслы, так и записи личного и публицистического характера»7.

Принципы публикации рабочих тетрадей, сформировавшиеся в самом начале изучения рукописного наследия Достоевского, следует считать взаимодополняющими. Рассмотрим возможности их применения по отношению 
к заявленной нами теме изучения графических особенностей рукописей Достоевского на материале его ранних записных книжек и тетрадей.

«Целостный» подход к исследованию записных книжек и тетрадей перспективен, например, для сбора, анализа и систематизации сведений об особенностях использования писателем невербальных элементов его рукописей; выявления устойчивых характеристик оформления им своих текстов (расположение на странице основного текста и маргиналий ${ }^{8}$, авторская маркировка записей, порядок заполнения тетрадей и т. д.); общих, устойчивых признаков почерка писателя (например, характеризующих пространственную ориентацию (размещение) движений на листе), что может стать одним из направлений при исследовании графики раннего Достоевского.

Однако заявленный принцип публикации отнюдь не отменяет (при появлении другой, более узкоспециальной задачи) возможности и бо̀льшего удобства использования другого типа воспроизведения материала (или части материалов) записных тетрадей: с извлечением из них, сведѐнием воедино и компоновкой однородных видов записей, как это происходило с материалами к его романам. Поясним сказанное.

Среди всех разнородных материалов, составляющих содержание записных книжек и тетрадей, в наименьшей степени изучены и опубликованы расчеты, записи, относящиеся к редакционно-издательской деятельности Достоевского (состав будущих номеров журналов «Время», «Эпоха» и «Гражданин», подсчеты будущих продаж, проекты изданий), записи долгов. Долгое время они вообще оставались недоступными широкому кругу исследователей. К ним иногда обращались биографы писателя'; расчеты из двух тетрадей (РГАЛИ. Ф. 212.1.8, 212.1.9) и двух записных книжек (ОР РГБ. Ф. 93.I.1.4, 93.I.1.5) в 1935 г. были частично воспроизведены Е. Н. Коншиной ${ }^{10}$. Однако полный свод всех расчетов в печати не появлялся. Только в 1971 г. они были в первый и единственный раз, с некоторыми ошибками расшифровки и лакунами ${ }^{11}$, опубликованы в 83 т. «Литературного наследства». Отсутствие позднейших републикаций расчетов исключило возможность корректировки неточных прочтений рукописи (от которых не застрахован ни один текстолог) и снизило возможности их дальнейшего анализа другими исследователями, не имеющими доступа к первоисточнику. Кроме того, сам способ подачи материала (в корпусе отдельных записных тетрадей), в целом оправданный, в плане изучения наименее исследованной области деятельности писателя - журналистской, издательской и редакторской оказывается не самым удачным.

Приведем пример: в ранних записных книжках и тетрадях Достоевского: в трех указанных (ОР РГБ. Ф. 93.І.2.7, 1862-1864, Ф. 93.I.2.8, 1864-1865 (записи из нее никогда не публиковались), РГАЛИ. Ф. 212.1.3, 1864-1865), а также в еще одной записной тетради (РГАЛИ. Ф. 212.1.4, 1864-1865 ${ }^{12}$ ) и в более ранней записной книжке (ОР РГБ. Ф. 93.І.2.6, 1860-1862 $\left.{ }^{13}\right)$ - содержатся расчеты, в т. ч. по будущему предполагаемому изданию, подсчеты личных 
долгов и записи издательского характера по журналу «Эпоха», когда после смерти брата писателю пришлось взять на себя хлопоты по формированию состава будущих номеров и расчетам с подписчиками. Три из них велись, как это нередко бывало, параллельно; записи изо всех пяти рабочих тетрадей перекликаются, дополняют, иногда повторяют друг друга, что приводит к мысли о необходимости издания всех этих материалов не вразброс, а единым корпусом текстов. Это «пятикнижье» естественным образом дополняют никогда не издававшиеся две так называемые приходно-расходные книги по журналам «Время» и «Эпоха», которые велись сначала Михаилом Михайловичем, а после его смерти - Федором Михайловичем Достоевским (ОР РГБ. Ф. 93.І.3.21, сентябрь 1860 - июнь 1865 и Ф. 93.I.3.22, 1861-1865), а также записи на отдельных листках (ОР РГБ. Ф. 93.I.3.51, 93.I.3.23/1-6; см.: [Нечаева, 1957: 276-277]). Утвердившийся в науке о Достоевском способ репрезентации издательских записей и расчетов из указанных тетрадей: когда сделанные в один день или с разницей в день-два тесно связанные между собой или просто однотипные записи находятся на большом удалении друг от друга, в разных записных тетрадях, либо не опубликованы вовсе - препятствует полноценному их анализу для изучения издательской деятельности писателя начала 1860-х гг., уточнению фактов его биографии данного периода. При расшифровке рукописей, кроме того, возникало много ошибок, большая часть которых обнаруживается благодаря анализу авторского почерка, сопоставлению одновременно сделанных записей, исследованию контекста (который при таком типе публикации отражается обычно не в полном объеме).

Подготовка издания, которое объединило бы в себе однотипные записи с расчетами из всех семи указанных архивных единиц (заново расшифрованные, систематизированные, проанализированные и снабженные полным комментарием $\left.{ }^{14}\right)$, - дело будущего. В настоящей статье укажем на несколько видов ошибок, встретившихся при воспроизведении таких записей, описав предварительно их расположение в каждой из трех анализируемых тетрадей.

Исследователями отмечался особый характер заполнения Достоевским записных книжек и тетрадей, затрудняющий работу по их анализу и публикации. Это хаотичное, на взгляд стороннего наблюдателя, непоследовательное внесение записей, часто в прямом и обратном направлениях (когда книжка переворачивается и текст вписывается с противоположной стороны). При этом разновременные записи на одной странице могут быть расположены как в прямом, так и в обратном направлении, оказываясь вписанными туда, где оставалось свободное место. Страницы заполнялись не подряд, иногда с пропуском нескольких листов, так и остававшихся чистыми. Часто несколько тетрадей велись одновременно.

Не являются в этом отношении исключением и три указанные рабочие тетради. Проанализируем более подробно записную тетрадь 1864-1865 гг. 
(РГАЛИ. Ф. 212.1.3). Она имеет 147 страниц (из них 28 незаполненных), пронумерованных как в прямом, так и в обратном направлениях, и один вставной титульный лист, на котором, в «прямом» направлении А. Г. Достоевской сделано описание данной тетради (именно он теперь и определяет основное направление текста). Записи, сделанные в «обратном» ${ }^{15}$ направлении, - хронологически наиболее ранние в тетради, - непосредственно продолжают аналогичные записи из книжки 1862-1864 гг. ${ }^{16}$ (ОР РГБ. Ф. 93.I.2.7) и содержат рабочие записи по журналу «Эпоха» ${ }^{17}$ (крайние даты: 21 августа 1864 г. - 2 февраля 1865 г.), черновые планы номеров на июль ноябрь 1864 г. с примерным подсчетом листажа каждой статьи ${ }^{18}$ и, на двух разворотах, примыкающие к ним записи для памяти ${ }^{19}$ (подсчет долгов, как личных, так и рабочих - фабрикантам, поставщикам бумаги и авторам).

Записи по «Эпохе» сделаны как чернилами (иногда угасающими), так и карандашом (часто полустертым), скорописью, с исправлениями (зачеркиваниями, вписками), непрописанными концами слов, сокращениями и повторами. Последнее является одной из характерных особенностей данного вида записей у Достоевского во всех его тетрадях: даже в пределах одной страницы подсчеты (рабочих расходов, личных долгов) или черновые планы номеров журнала, записанные, как правило, в столбик, могут повторяться по два, три, четыре раза; нередки случаи, когда однотипные записи находятся на нескольких, иногда удаленных друг от друга страницах и даже в разных тетрадях. Проставленные справа, после каждой фамилии числа (размер ли долга, или предполагаемое количество печатных листов будущей статьи или подписчиков и продаж) могут быть продублированы тут же карандашом, с целью произвести промежуточный или окончательный подсчет. При расшифровке подобного вида записей, помимо очень внимательного (с учетом всех затрудняющих прочтение моментов: недописанных концов, сокращений, вариативности написания одних и тех же названий, полустертого карандаша или угасших чернил) изучения графического образа слов и цифр (об особенностях их написания см. Приложение), следует опираться на сравнительный анализ контекста, учитывая идентичные записи в пределах даже одной страницы.

К названным деловым записям по журналу «Эпоха», уже известным по публикации «Литературного наследства», прибавим еще две, до этого не известные. Они связаны с одной из особенностей заполнения Достоевским записных книжек и тетрадей: достаточно часто записи его рукой можно обнаружить не только непосредственно на страницах тетради, но и на форзаце и нахзаце ${ }^{20}$. Есть подобные записи и в данной тетради. И если текст первой, на форзаце, записанный хотя и угасающими чернилами, но отличающийся большей степенью сохранности, был недавно прочитан при подготовке цифрового архива Достоевского в рамках научно-исследовательского проекта под руководством С. А. Кибальника, то о записи на нахзаце, практически угасшей (см. Илл. 31), не было даже известно. Приведем 
записи, заметив, что представилось возможным предложить прочтение лишь нескольких еле видимых слов из угасшего текста, находящегося на нахзаце. Для прочтения остальной части необходимы специальные технические средства, которые позволили бы идентифицировать написания.

Запись на форзаце, в направлении, обратном основному, угасающими чернилами

$<н р 3 б .>^{21}$

Зименко къ кониу Февраля

$<1865$ г. $>$

Федорову - справиться $\{$ въ

Январпь <1865 г. $\left.>^{22}\right\}$

Гериху къ 7му Января <1865 г.>

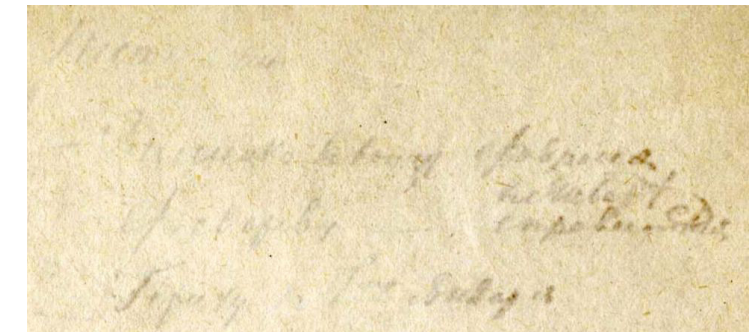

До $10^{20}$ числа Января <1865 г.> По векселю $\underline{625}$

Демисъ NB

Типограб<ія > и бумага 700

Aвторь - 1000

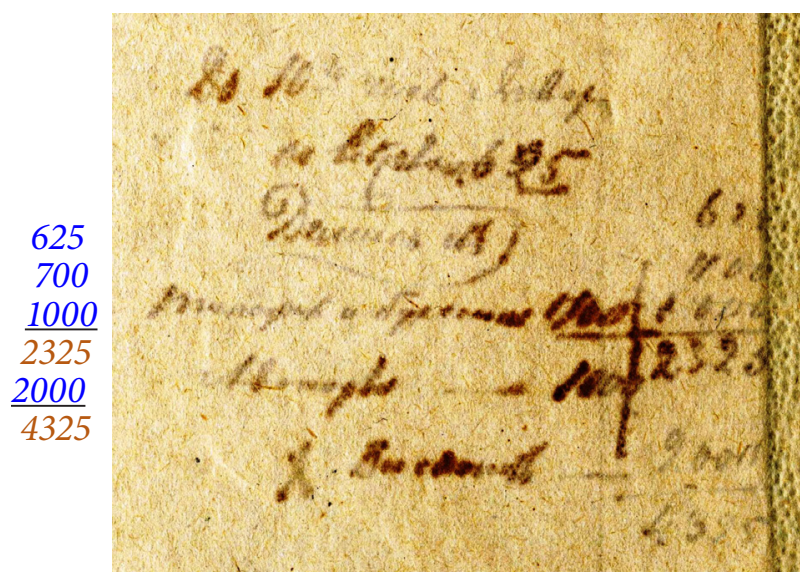

$x$ Вгомникъ $<i>-$

Первая запись очевидно коррелирует с расположенной почти в конце тетради (с. 133 (15)) записью для памяти с перечнем адресатов, относящейся к тому же периоду и написанной также в обратном направлении:

$$
\begin{aligned}
2^{е} \text { Февраля } & <1865 \text { г.> } \\
& x \text { Тургеневу } \\
& x \text { Зименко } \\
& - \text { Врангелю } \\
& - \text { Шилловскому } \\
& - \text { Шейну } \\
& - \text { Чаеву } \\
& - \text { Брату Андрею. }
\end{aligned}
$$

Omвиччать.

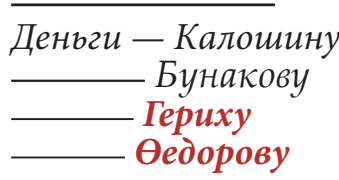


Проиллюстрируем еще раз на примере одного, наиболее плохо прочитывающегося в первой записи слова - фамилии «Зименко» (особенно пострадала от времени заглавная «3», которую можно только угадывать «по общему рисунку»), — возможность практического применения «таблиц написаний <...> букв» и целых «альбомов по отдельным писателям», о которых С. А. Рейсер писал, как о «чрезвычайно важном пособии» «в редакционно-текстологической работе» и «при подготовке к печати его [писателя] литературного наследия» [Рейсер: 80].

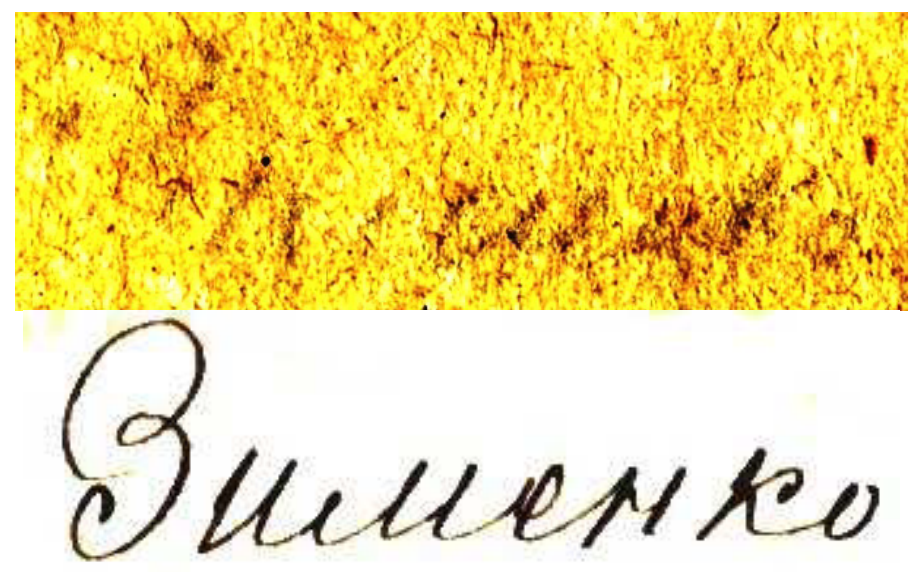

Илл. 29. Графические очертания слова «Зименко» (угасающие (форзац) и четкие (с. 133) чернила)

Первое слово из записи на форзаце однозначной расшифровки не нашло. С большой долей вероятности можно согласиться с расшифровкой: «Теaтрг - 1 л.», - помня о предположительности этого чтения. Приведем иллюстрации данного слова, а также слова «театръ», написанного мягким карандашом и четкими чернилами, встречающегося на соседних страницах тетради (рубрика «Русский театр в Петербурге» А. Григорьева, а потом Аверкиева присутствовала в 1-2, 3, 6, 7, 9, 10-м номерах «Эпохи»):

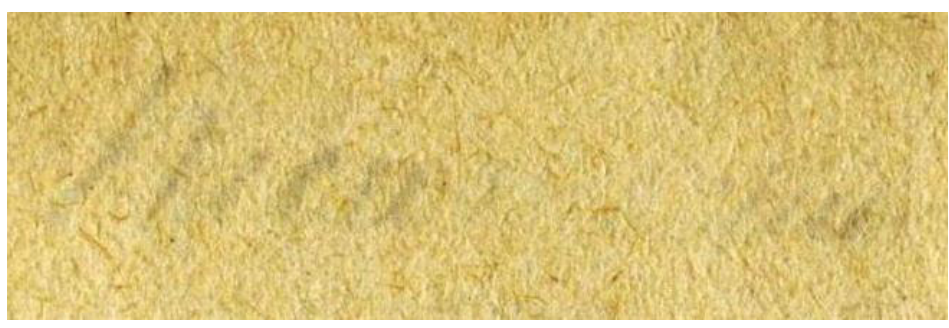




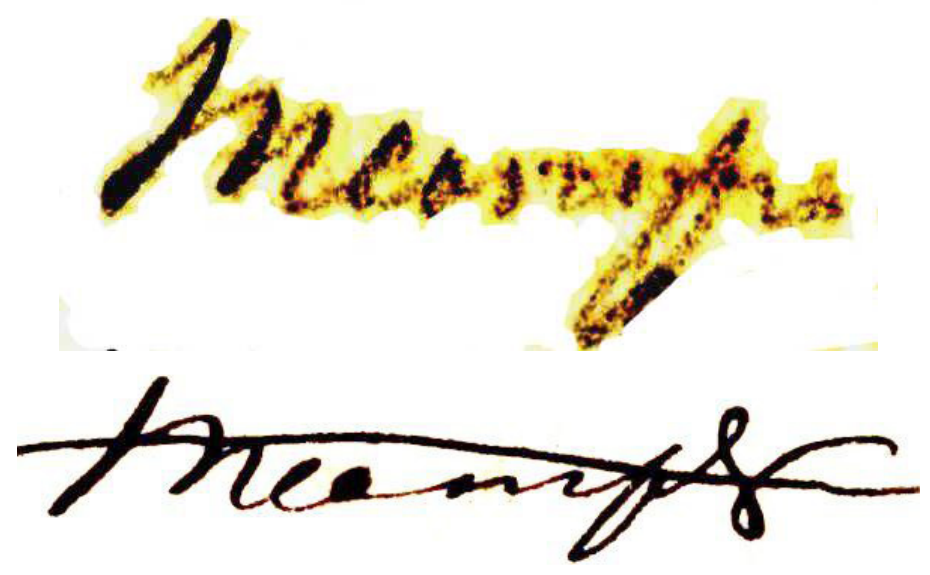

Илл. 30. Графические очертания слова «Театръ»

(форзац - угасающие чернила, прочитывается под вопросом,

c. 2 - мягкий карандаш, с. 5 - четкие чернила)

Во второй же приведенной записи находится пример упомянутой выше характерной для писателя манеры заполнения расчетами страницы (многочисленные цифры его расчетов часто вызывают трудность как в точном прочтении, так и в точном отнесении к определенному месту на странице): первоначальные цифры долгов (выделены в расшифровке выше зеленым цветом) продублированы тут же, в столбце справа (выделены голубым цветом), с подсчетом промежуточных и итоговых сумм (выделены коричневым цветом). Наибольшие затруднения при расшифровке цифр в данной записи могут вызвать «7», «2», схожая с цифрой «9», и «0», овал которой не всегда пишется закрытым, что может приводить к смешению с «6» (варианты написания цифр см. в Приложении). Однако вспомогательным средством при расчетах выступает математическая проверка примера (при сложении должен получиться результат, прописанный под чертой, - конечно, если сам автор не ошибся в расчетах), а также сравнение с более четко прописанными числами в однотипных, дуплетных записях.

Приведем также иллюстрацию и предварительное описание обнаруженных неопубликованных записей на нахзаце данной тетради. Они располагаются двумя группами: две строки в верхнем правом углу и семь строк в нижней правой части страницы, в направлении, обратном основному. 


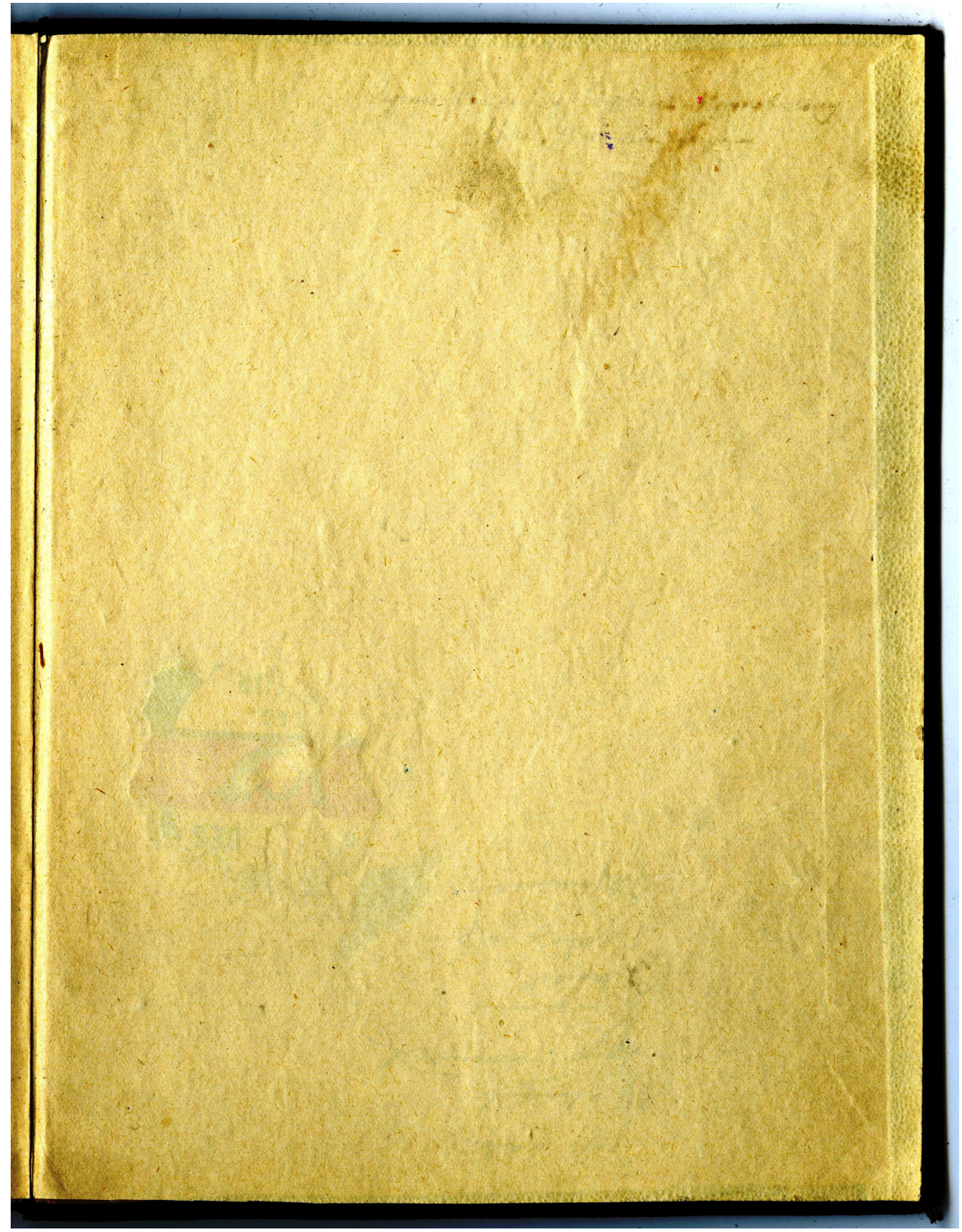

Илл. 31. Нахзац ЗТ (РГАЛИ. Ф. 212.1.3)

Наверху в первой строке прочитываются имя, отчество (под вопросом) и фамилия; во второй строке видно только начальное «в»: 


\section{Сергпю Сергпевичу< $>$ Корвинъ-Круковскому въ <нрзб.>}

В нижней записи - семь коротких строк, вероятно, занятых записями долгов. Предположительно читаются только начало первой («3 руб.») и третьей («2 руб.») строки.

Проанализировав страницы из трех указанных рабочих тетрадей, содержащие перечни будущих статей для нескольких номеров журнала «Эпоха», можно сказать еще об одной особенности, позволяющей, наравне с сопоставлением однотипных записей (на одной или разных страницах или даже в разных тетрадях), проверить точность прочтения записи по графическому рисунку (в случаях нечеткого, с трудом поддающегося расшифровке написания). Каждая статья в этих перечнях кратко названа по имени ее автора, или по псевдониму, которым он подписывался в журнале, или по ее названию. Причем название одной и той же статьи могло варьироваться в пределах даже одной страницы - в повторном списке. По-разному могли писаться также и псевдонимы одного автора. Название же статьи (поскольку это были краткие записи «для себя») писалось часто в сокращенном, а иногда - в несколько измененном по сравнению с печатной публикацией виде. Неучитывание этих особенностей может приводить к ошибкам в прочтении, тем более, что графические характеристики данных видов записей (большинство сделано мягким толстым карандашом, где линии в буквах утолщаются, а четкость уменьшается; слова написаны скорописью, со слившимися почти в точку гласными, нечеткими концами, часто вообще не дописаны) не всегда способствуют четкой однозначной их расшифровке. Приведем несколько примеров.

В августовском номере «Эпохи» за 1864 г. начал печататься перевод, сделанный дальней родственницей братьев Достоевских, переводчицей Ю. П. Померанцевой ${ }^{24}$, романа популярного немецкого писателя Ф. Шпильгагена «Из мрака к свету» (1861-1862) - продолжения опубликованного ранее в «Эпохе» (№№ 1-4) романа «Загадочные натуры». Роман публиковался до конца 1864 г., и в планах номеров журнала неоднократно упоминается на страницах рабочих тетрадей Достоевского, то под точным названием, то в виде варианта «Изъ мрака въ свптъ» (с. 2 (147), дважды (карандаш, недописано), 3 (146), дважды (карандаш, недописано, чернила, полностью), 4 (145), дважды (чернила, полностью, карандаш, недописано)). Во всех приведенных примерах графические очертания предлога дают однозначное прочтение: «въ», а не «къ». Этот же измененный вариант названия находим в близкой по времени записи из $3 K_{2}$ (ОР РГБ. Ф. 93.I.2.7. С. 87 (71), чернила, полностью: «Сдано въ типографію Тиблена 19 Августа <...> Изъ Мрака въ свптъ»). Между тем в той же тетради, в более поздних по времени записях - в планах сентябрьского, октябрьского и ноябрьского номеров (с. 131 (17), 129 (19), 
чернила, полностью), а также в записи для памяти от 16 октября (с. 136 (12), чернила, полностью: «16) Октябр<я>. Справиться о 2ци и Зй части Изб Мрака къ Свюту») - встречаем уже точное название перевода. Оно же употребляется и в одной из приходно-расходных книг по журналу 1861-1865 гг. (ОР РГБ. Ф. 93.І.3.22. С. 18: «Для Ю. П. Померанцовой въ счетъ перевода Изъ Мрака къ свпту получилъ девяносто рублей»). Между тем в «Литературном наследстве», в силу фразеологической инерции, во всех шести случаях появления варианта названия в $3 T$ дана неточная расшифровка «Из мрака к свету» (ЛН, т. 83: 206-208), и только прочтение в $3 K_{2}$ правильное (ЛН, т. 83: 185).

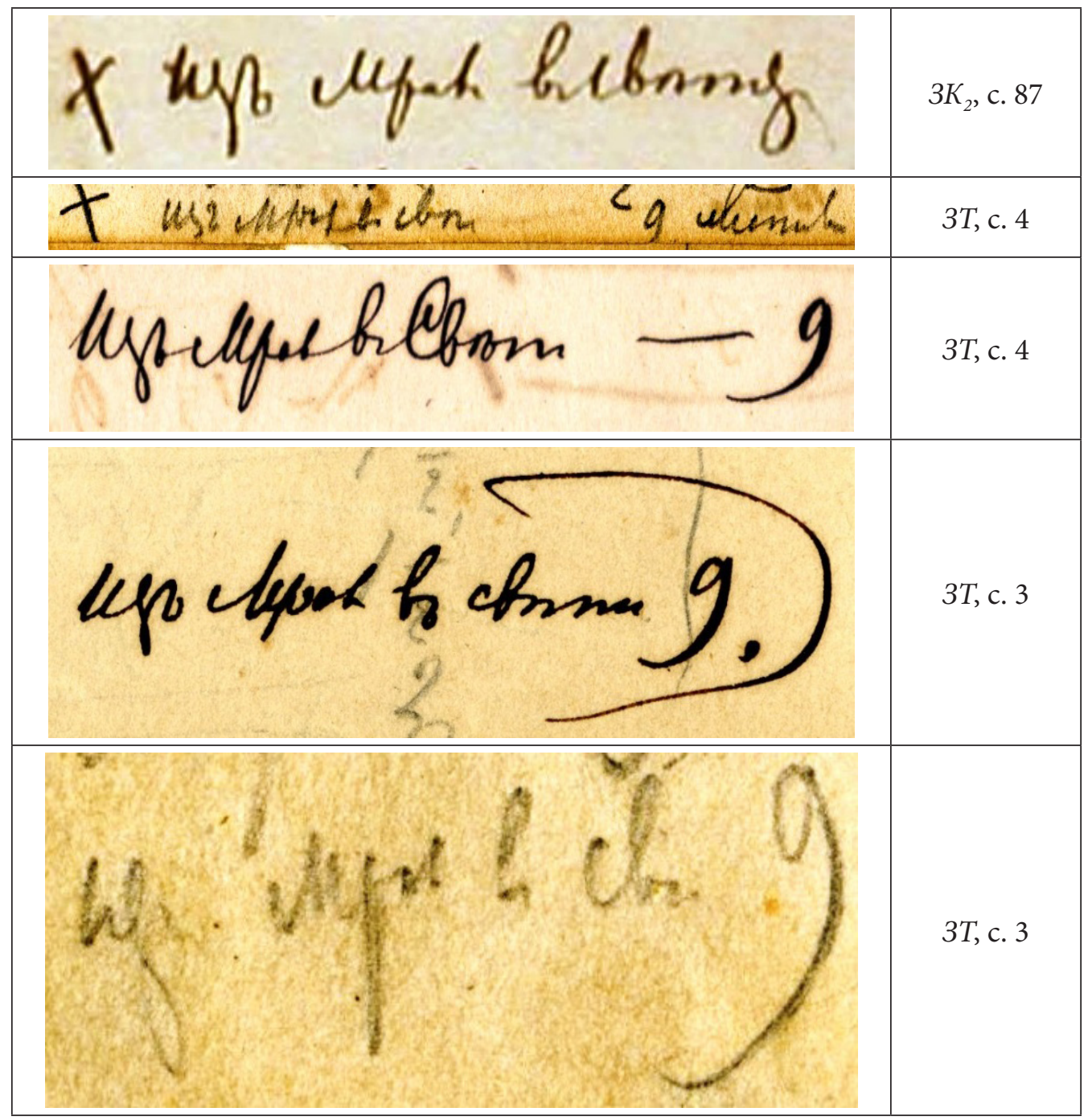




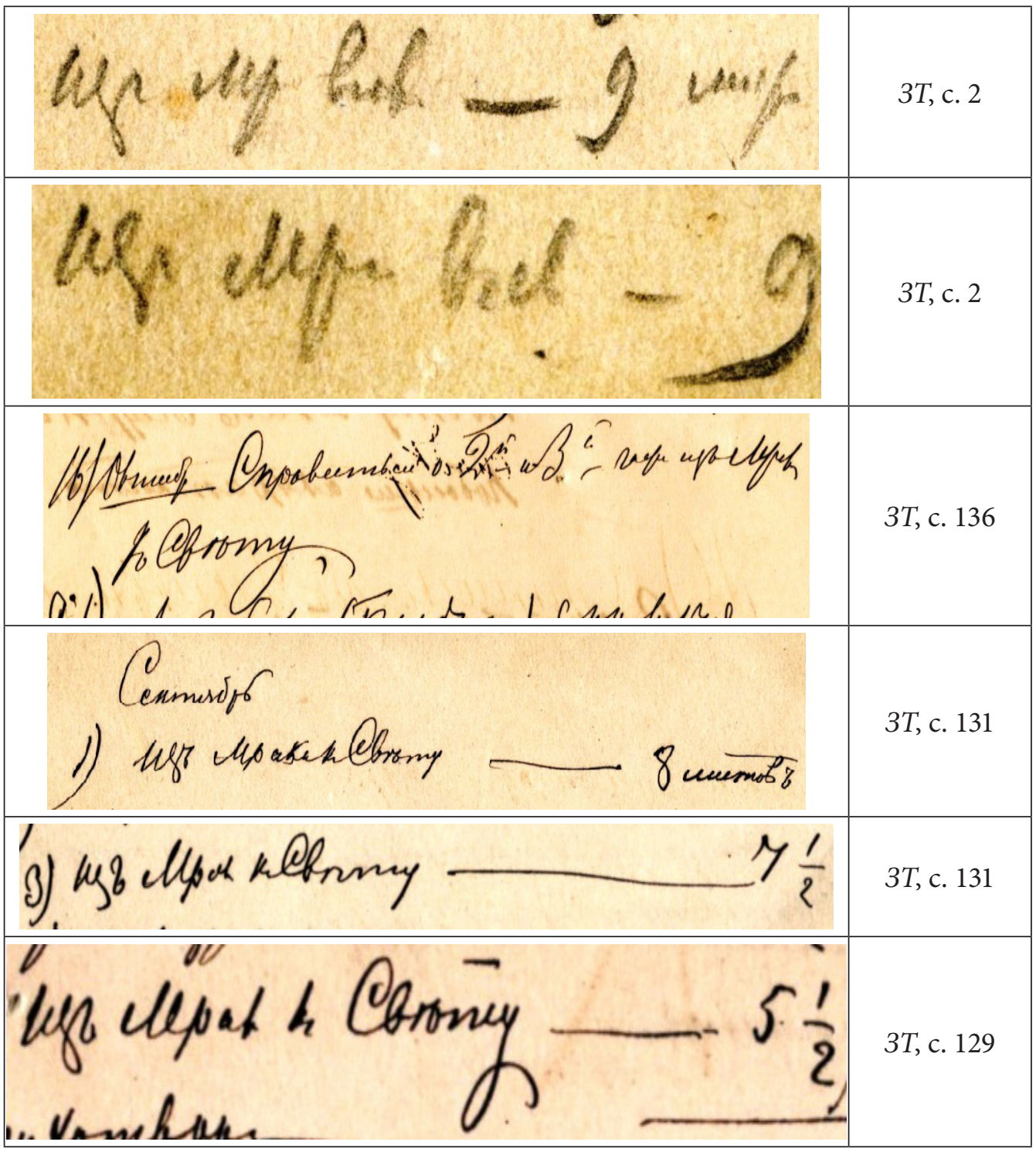

Табл. 17. «Из мрака к свету» / «Из мрака в свет»

Приведем пример вариативного написания псевдонима. В августовском же номере «Эпохи» 1864 г. была напечатана повесть «Лиза», принадлежавшая перу писательницы Софьи Владимировны Энгельгардт, урожденной Новосильцевой (1828-1894), публиковавшейся под псевдонимом «Ольга Н. (Ольга N.)» и обратившей на себя внимание Достоевского еще в 1850-е гг. [Нечаева, 1975: 132, 257, 288]. Сокращение в псевдониме могло писаться как кириллицей, так и латиницей, и в этих обоих вариантах оно встречается и в 3T, причем в одном случае - на одной странице в соседних столбцах. На нужные варианты прочтения указывают графические характеристики 
записей, но в ЛН (c. 205, 207) во всех пяти случаях написание унифицировано и дан только один вариант псевдонима: с латинской N. - так, как произведение подписывалось в печатном варианте.

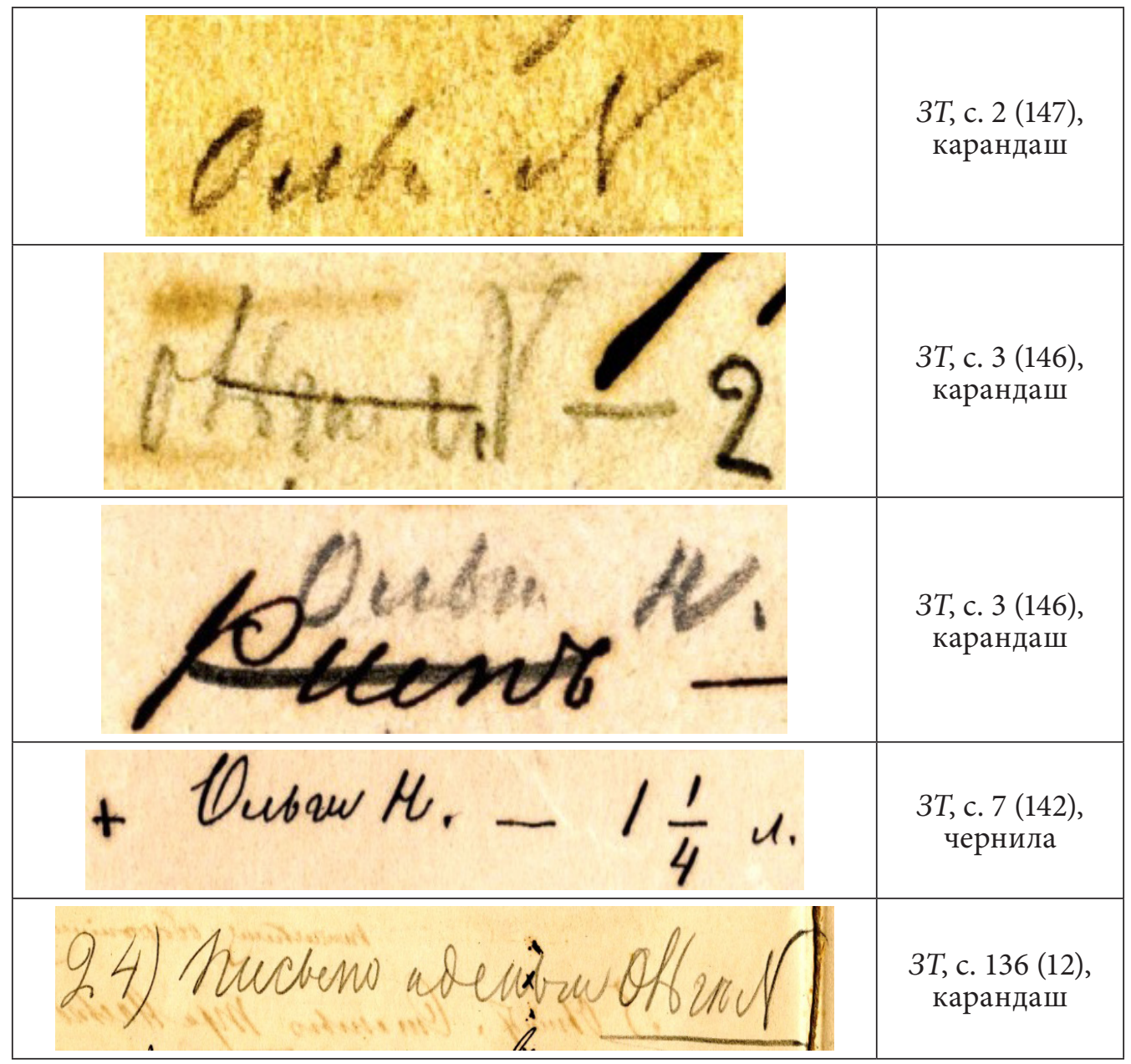

Табл. 18. Ольга Н. / Ольга N

В июльской книжке «Эпохи» (цензурное разрешение 19 сентября 1864 г.) были опубликованы две статьи А. Григорьева, в том числе статья о Д. В. Григоровиче ${ }^{25}$. В предыдущих номерах журнала печатались его же (Григорьева) «Парадоксы органической критики» (май. С. 255-273; июнь. С. 264-277; ценз. разр. 7 июля, 20 августа), в форме двух писем к Ф. М. Достоевскому. Судя по письму Григорьева к Достоевскому от конца августа, существовало и третье письмо «органического критика», предназначавшееся то для июльской, то для августовской книжек журнала (последняя задержалась выходом и была напечатана только в конце октября, уже после скоропостижной смерти А. Григорьева 25 сентября 1864 г.), но так и не опубликованное 
[Нечаева, 1975: 153-160]. Состав будущего июльского номера, постоянно уточнявшийся, несколько раз прописывается на страницах всех трех рабочих тетрадей Достоевского (записи датируются второй половиной августа, в $3 T$ - это семь планов июльской книжки на с. 5, 4, 3, 2). Статьи А. Григорьева там обозначены то его фамилией, то сокращенным названием одной или другой статьи: $3 K_{2}-$ «Григорьевъ 2 ли<ста>» (с. 32), «Для Іюля Григо-

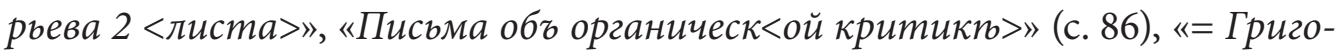

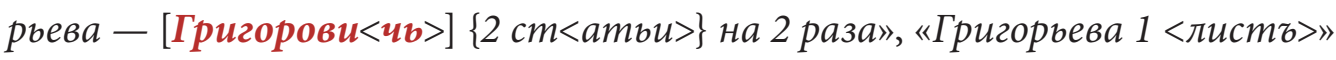
(с. 87), «Григорьева» (с. 91), 3К - «Органич<еская критика $>$ А. Григорьев<а>» (c. 39), «Письм<а> объ органическ<ой критикю > Гр <игорьева> - 1» (с. 40),

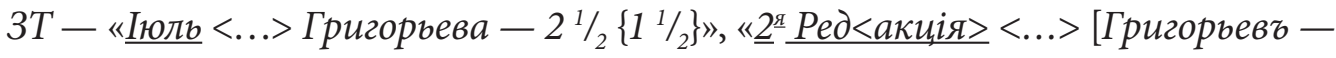

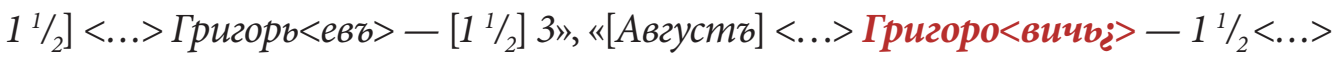
Органи<ческій критикъ> $-1 \frac{1}{2}$ ", «Григоров<ичв $>-1 \frac{1}{2}<\ldots>\{$ Органич<ескій

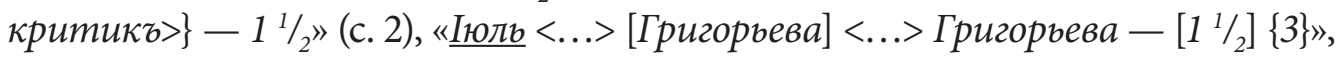
«ригор<вева> [1 $1 / 2]\{3\} »$, Августь <...> Орг<аническаго критика> $1 \frac{1}{2}$ ", "[Григорьевъ - $\left.1 \frac{1}{2}\right]<\ldots>$ Органич<ескаго критика> - $1{ }^{1}{ }_{2}$ " (с. 3), «Aвгусть <...> Григорьева Орг<аническая > Критика - 1 листь <...> NB Григорьева - 1 лис<ть>», «Орг<аническаго > Кри<тика> - 1 листь», "<Іюль > 7) Григорьева - 13/4» (с. 4), «польскій № <...> х Григорьева Григоров<ичь > $2\left\{{ }_{1}{ }_{2}\right\}$ л<иста>», «[7) О Григоровичп] <...> [\{Органич<ескаго> Критика\}] 8) О Григоровичп <...> 15) Письмо Органи<ческаго> Крит<ика>]» (с. 5), «Григорьева - 1» (с. 7), «<8 сентября> Заголовокъ статьи Григорьева (Григоровичь) <...> (NB. \{Поставить. $\}$ Статья первая)» (с. 139).

Выделенные коричневые цветом слова в ЛН трижды прочитаны неточно: «Григорьев» (с. 185, 208). Этому способствует и недописанность слов, и нечеткие их очертания (карандаш), и схожесть фамилий, и неучтенная в данном случае вариативность написаний у Достоевского. Однако графические очертания слов все-таки говорят в пользу уточненного прочтения (существует разница между написаниями буквосочетаний «ро» и «рь» у писателя: в последнем случае «ь» пишется выше строки; часто написание этой лигатуры совершается одним движением пера, без отрыва от листа, - что особенно четко видно в двух примерах, когда обе фамилии написаны рядом):

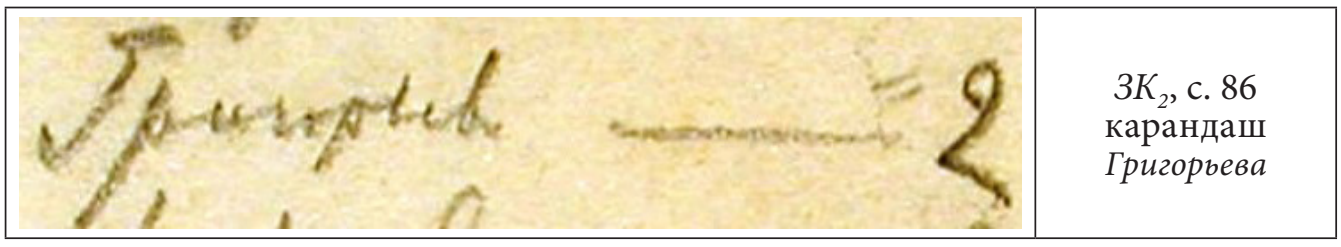




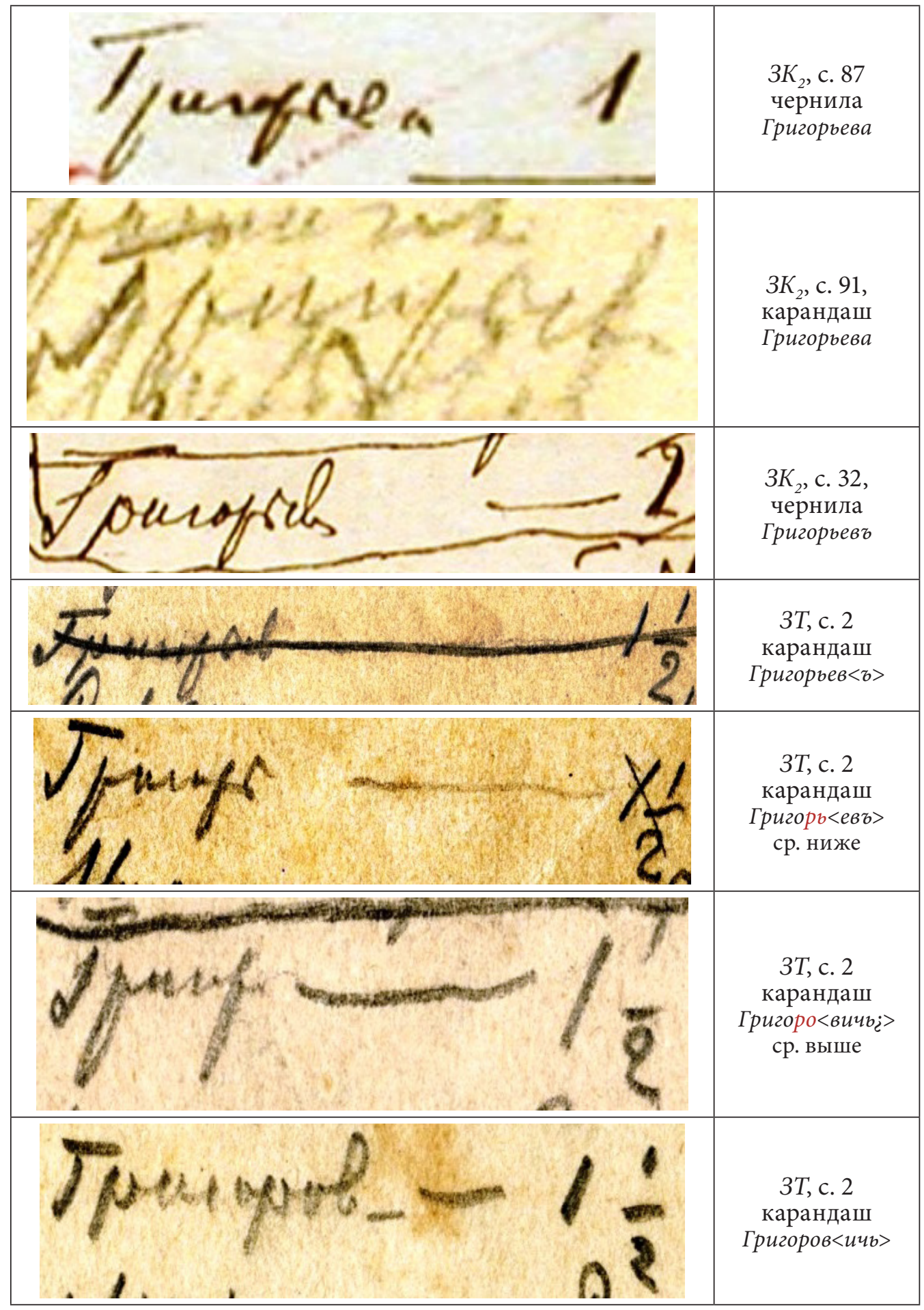




\begin{tabular}{|c|c|}
\hline $6 / 2 / \mathrm{xen}^{2}$ & $\begin{array}{c}\text { 3T, с. } 5 \\
\text { чернила } \\
\text { 8) О Григоровичь }\end{array}$ \\
\hline 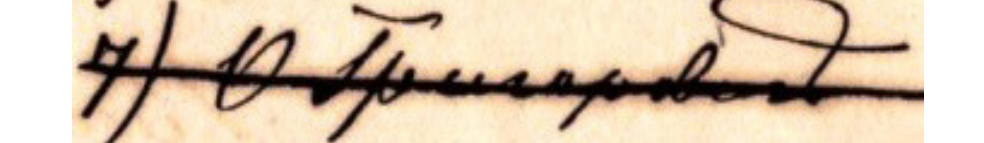 & $\begin{array}{c}3 T, \text { с. } 5 \\
\text { чернила } \\
\text { [7) О Григоровичи] }\end{array}$ \\
\hline$r$ & $\begin{array}{c}3 K_{2}, \text { с. } 87 \\
\text { карандаш } \\
\text { Григорьева- } \\
\text { Григорови<чь> }\end{array}$ \\
\hline $2, \frac{1}{2}$ & $\begin{array}{c}3 T, \text { с. } 5 \\
\text { чернила } \\
\text { Григорьева } \\
\text { Григорови }\langle\text { чь }>\end{array}$ \\
\hline Sarolubob cmambs Jurevobeb (Jp & $\begin{array}{c}3 T, \text { с. } 139 \\
\text { чернила } \\
\text { Григорьева } \\
(\text { Григоровичь) }\end{array}$ \\
\hline
\end{tabular}

Табл. 19. Григорьев / Григорович

Контекстуальный анализ, сопоставление с записями на других страницах, относящимися к росписи одного номера, помогают исправить ошибку чтения и в следующем случае: «Театръ» (3T, с. 5) вместо неверного: «Театраль» (ЛН, т. 83: 206). В июльском номере журнала (с. 19-20) опубликована статья «Русский театр в Петербурге. Голос старого критика» А. Григорьева, исполнявшего в «Эпохе» роль не только критика, но и театрального рецензента. Ошибка была вызвана нечастотным написанием буквы «ъ», действительно, похожей в этом варианте на лигатуру «ль». Исправлению прочтения может служить в данном случае еще дважды упомянутое название этой статьи - на этой же и на 2-й странице (ср. также с другим вариантом написания этого же слова в названии статьи Аверкиева, заступившего после смерти А. Григорьева на место театрального рецензента журнала; см. также примеры выше):

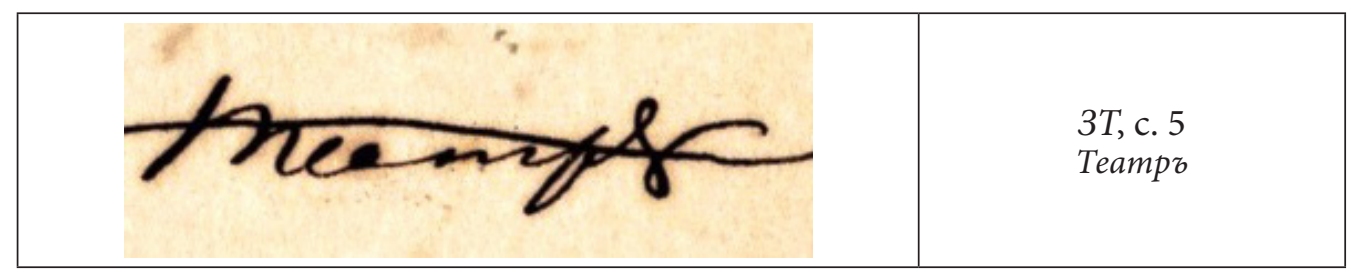




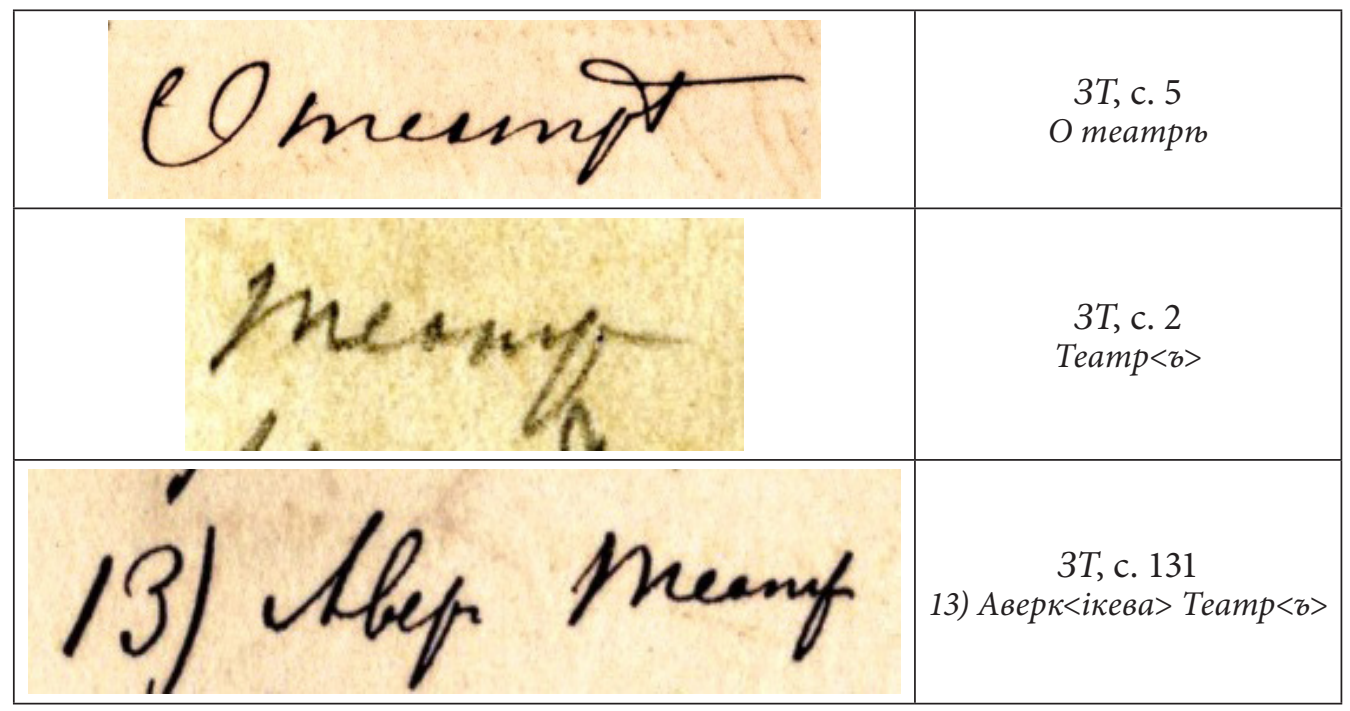

Табл. 20. Театр

Из записей, связанных с расчетами и начертанием цифр, входящих в корпус 3T, нужно также назвать записи по задуманному Достоевским периодическому изданию под условным названием «Записная книга» (расчеты - c. 25-43 по прямой нумерации, 124-106 - по обратной; и примыкающий к ним текст - с. 23-24; опубл.: ЛН, т. 83: 219-234). Все эти записи сделаны в прямом направлении, карандашом (с. 25-29, 34-36) и чернилами (c. 30-33, 37-43).

Характер заполнения страницы тот же, что и при записях по журналу «Эпоха»: прописывается в столбик (иногда в два) предполагаемое количество подписчиков будущего издания по месяцам (отдельно по двум столицам и по провинции) и доход от продаж издания по разной цене; тут же просчитывается стоимость всех типографских расходов и подводится баланс. Параллельно рядом на полях справа и слева делаются промежуточные расчеты в столбик. Еще одной особенностью расчетов является частое округление чисел в бо̀льшую сторону, если это прибыли (в мѐньшую - если долги) - тогда в соседнем столбике будет повторяться пример именно с такими округленными числами. Анализ и некоторая систематизация ошибок и пропусков в публикации расчетов в ЛН позволяют сделать вывод, что для корректного отражения данных видов записей при издании необходимо: 1) учитывать особенности начертания цифр у Достоевского (см. Приложение); 2) проводить для контроля, при сомнительных чтениях, математическую проверку расчета; 3) правильно группировать записи. Обобщим некоторые виды ошибок.

I. Смешиваются цифры «7» и «4», отличающиеся в начертании Достоевского, «6» и «8», «9» и «2», «1» и «4» (с. 25, 41, 43; 40; $38 ; 39-$ ЛН, т. 83: $219,231,232 ; 230 ; 229 ; 230)$ - во всех указанных случаях цифры являются 
частью чисел-слагаемых и точную цифру, помимо самой графики, подсказывает контрольное сложение в столбик: 960 : 7 = 137; предполагаемое число подписчиков № $12-25$ (Петербург) +15 (Москва) + 20 (провинция) = 60; предполагаемое число подписчиков № $7-125$ (Петербург) + 75 (Москва) +125 (провинция) $=325 ; 2700+2700+1350=6750$ (неверно прочитанные цифры выделены коричневым цветом). Несколько раз за цифры были приняты буквы и наоборот: «[При 5]» (с. 30) / «[Приб]» (ЛН, т. 83: 224), «no 4» (с. 33) / «104» (ЛН, т. 83: 226). Иногда добавляются отсутствующие в рукописи цифры («480», с. 25 - «4801», ЛН, т. 83: 219), иногда пропускаются имеющиеся («2 p. 70 коп.», с. 25 - «2», ЛН, т. 83: 219; «5000», с. 25 - «500», ЛН, т. 83: 220). Несколько случаев ошибочной замены цифр не мотивированы начертанием («16», с. $25-$ - $15 », ~ Л Н$, т. 83: 219; «46», с. 25 - «47», ЛН, т. 83: 220; «2 1/2», с. $31-\ll 11 / 2 », \pi H$, т. 83: 224).

II. Некорректно отражаются группы чисел, связанных между собой: часто они напечатаны отдельно друг от друга, создавая впечатление хаотического нагромождения огромного количества непонятных чисел на странице, являясь между тем частью единого математического примера (например, деления в столбик, сложения), и должны транскрибироваться именно таким образом (одной группой, отделенной от другой группы пробелом). Неучитывание этой связи чисел приводит также к двум ошибкам, когда окончательная итоговая сумма оказывается вписана не в тот столбик чисел, к которым относится, а в соседний (см. «2460» и «1730» на с. 39 / в ЛН, т. 83: 230 - не на том месте и с ошибкой: «2160» и «1730»)

III. Подсчет предполагаемого количества подписчиков по каждому номеру месяца - в ЗТ он дается в столбик отдельно по Петербургу, Москве, провинции, все три числа суммируются, и всегда рядом, справа или слева, те же расчеты, часто с округлением в бо̀льшую сторону, повторяются (в этом втором столбике подводится внизу страницы окончательное итоговое число подписчиков за год - см. Табл. 21) - корректнее и понятнее для читателя представлять с отбивкой каждого месяца друг от друга. Возможно, при такой подаче расчетов не возникали бы пропуски (см. лакуны в ЛН, т. 83: 234 - где ошибочно объединены данные за №№ 7 и 8 со с. 43, и пропуск описания № 8 на с. 33 - ЛН, т. 83: 226).

\begin{tabular}{|c|c|c|c|c|c|}
\hline 50 & По вblx< $<0 \partial n>8^{20}$ № & Петерб<ургъ> & 50 & \multicolumn{2}{|l|}{$=370$} \\
\hline 30 & & Москва & 25 & +37 & 407 \\
\hline 40 & & провини< <ія> & $\underline{35}$ & \multicolumn{2}{|l|}{407} \\
\hline$=120$ & & & 110 & & \\
\hline 40 & $9^{200} №$ & Петерб<үргбъ> & 40 & & \\
\hline 30 & & Москва & 20 & $=370$ & $=370$ \\
\hline 40 & & провини< <ія> & $\underline{40}$ & & \\
\hline$=110$ & & & 100 & & \\
\hline$<\ldots\rangle$ & & & & & \\
\hline 2705 & & & & & \\
\hline
\end{tabular}

Табл. 21. Пример расположения на странице расчета подписчиков на №№ 8-9 планируемого издания. (3Т. С. 40; ср. ЛН, т. 83: 230) 
Все вышесказанное говорит об актуальности проблемы исследования этой, пока малоизученной, группы текстов, посвященной записям издательского характера и расчетам Достоевского, критического их анализа, систематизации данных об их особенностях (в т. ч. графических) и как итог создания сводной комментированной научной публикации всех подобных записей, объединенных тематически и хронологически, из всех рабочих тетрадей писателя.

\section{Приложение}

Ниже представлены промежуточные результаты графического анализа цифр в рукописях Достоевского, дополняющие составленную в прошлом году таблицу начертаний букв ${ }^{26}$. Все десять цифр проиллюстрированы примерами их написаний в записной тетради 1864-1865 гг. (РГАЛИ. Ф. 212.1.3. С. 30) и сопровождены описанием. Для большей наглядности цифры сгруппированы не по возрастанию, а так, чтобы рядом находились те, которые могут смешиваться при расшифровке записей исследователями.

Таблица цифр

Цифра




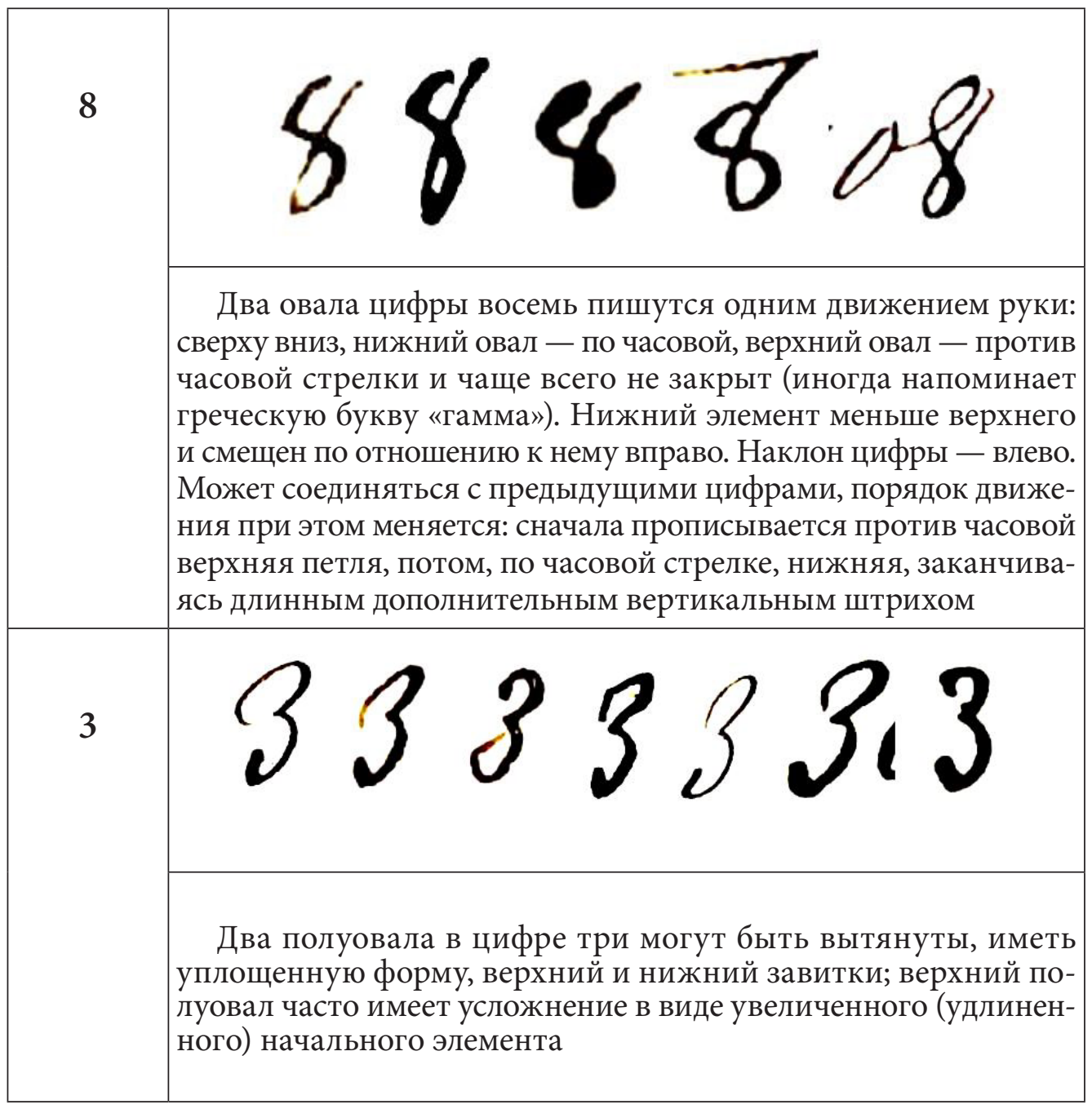




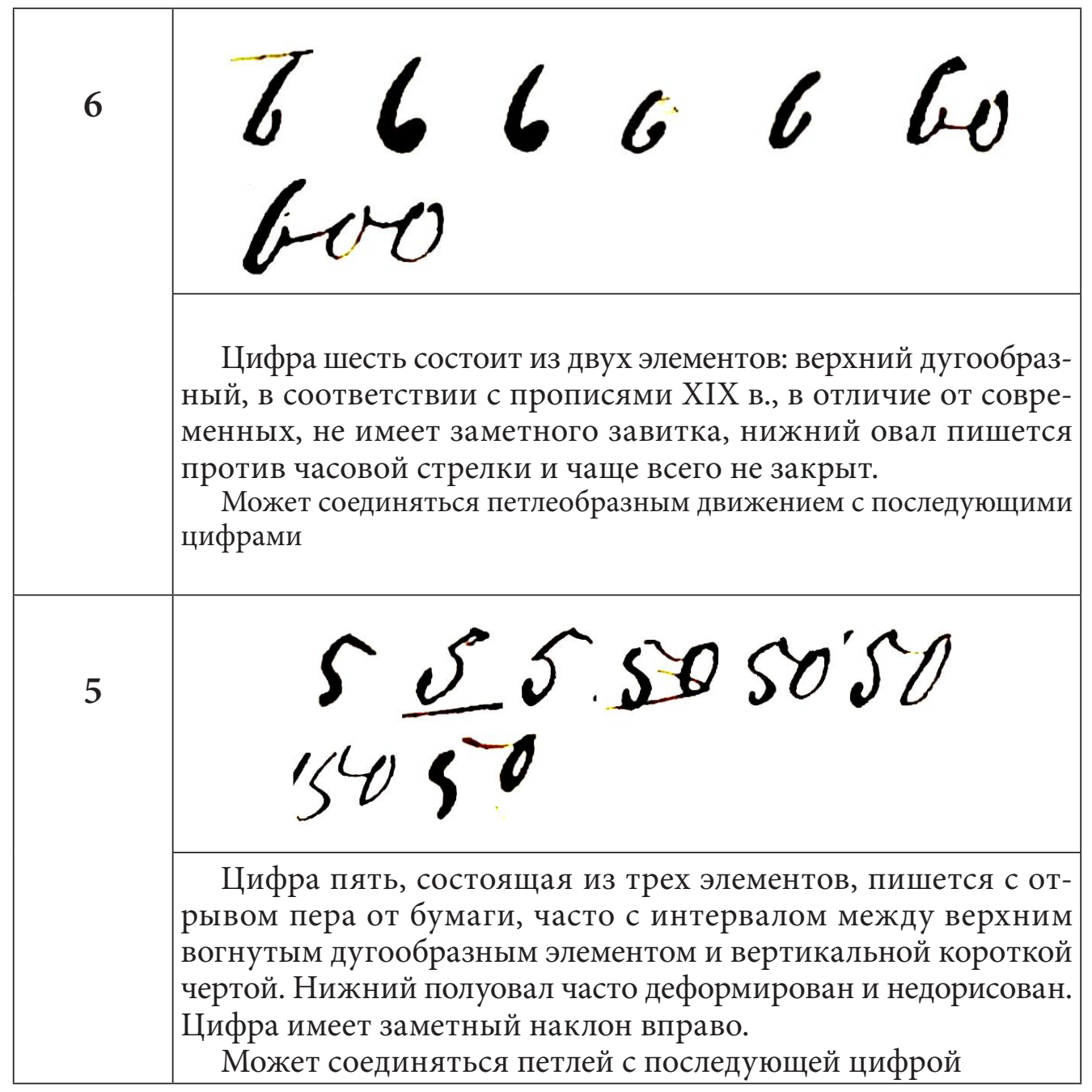


130

М. В. Заваркина, Т. В. Панюкова, Н. А. Тарасова

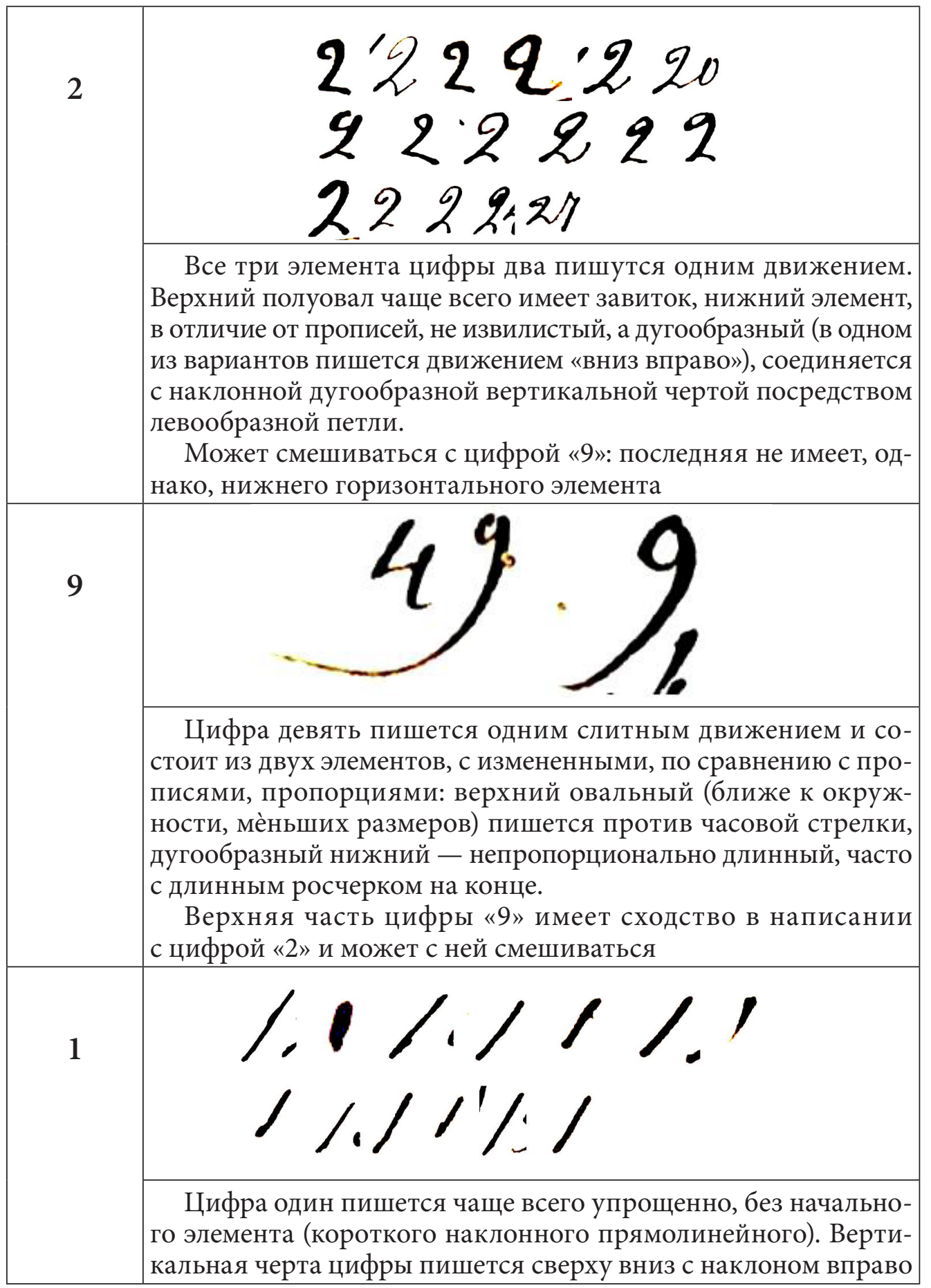




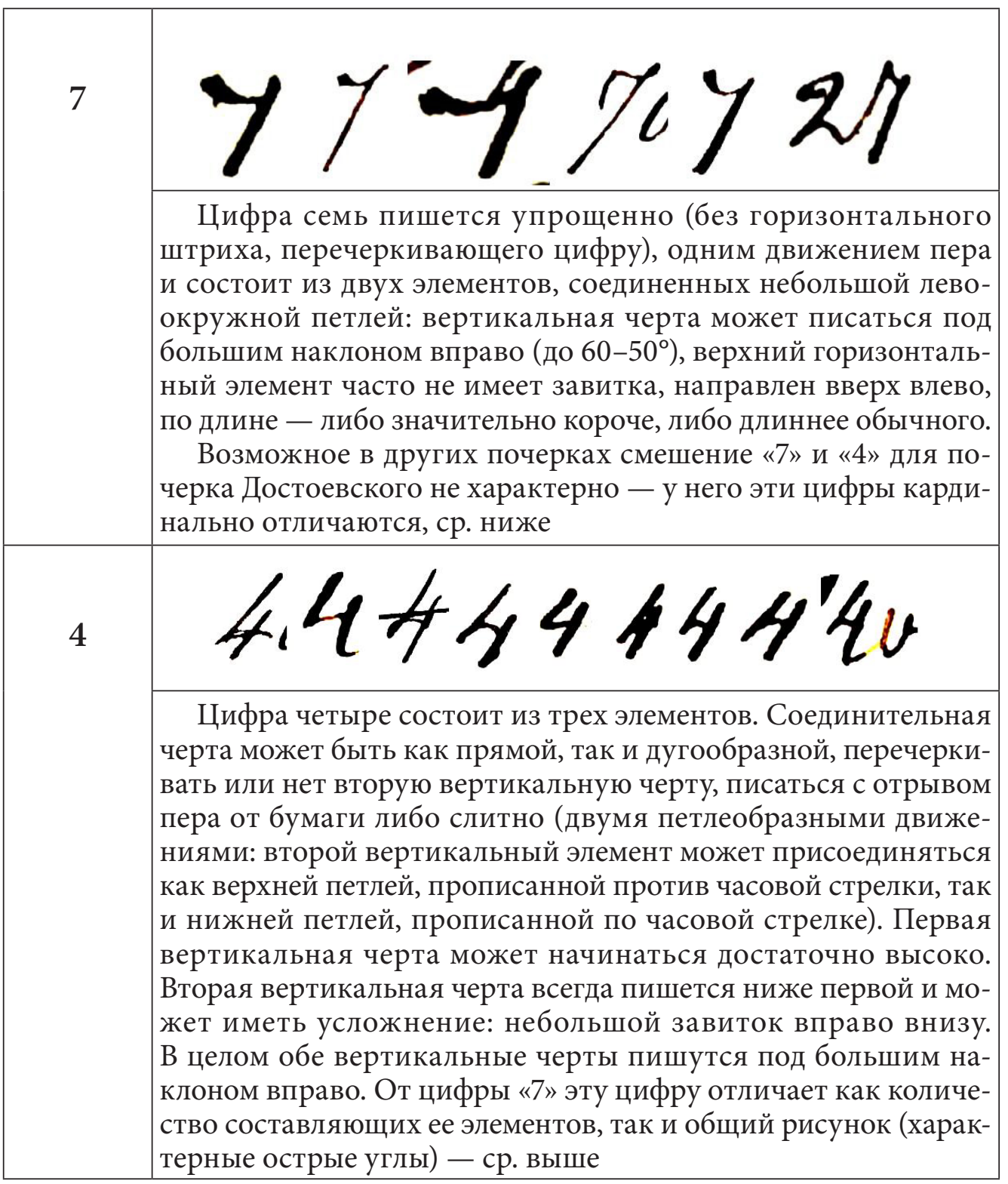

\section{Примечания}

* Исследование выполнено при финансовой поддержке РФФИ, проект «Подготовка материалов для информационной базы данных "Графические особенности рукописей Достоевского (конец 1850-х — первая половина 1860-х годов): почерк — язык - смысл”» № 18-012-00129.

1 Обзор версий, существующих на сегодняшний день по поводу начальной датировки записей из этой записной книжки, см.: [Заваркина].

2 Подробнее об этом см.: [Розенблюм, 1971: 27], [Фридлендер: 105].

3 Там же. 
4 Достоевский Ф. М. Полн. собр. соч. Ф. М. Достоевского. Т. 1: Биография, письма и заметки из записной книжки с портретом Ф. М. Достоевского и приложениями. СПб., 1883. 839 с.

5 Публикации Н. Л. Бродского (1922-1931, «Житие великого грешника»), Р. И. Аванесова (1927, «Двойник»), Н. Ф. Бельчикова (1928, «Крокодил»), И. И. Гливенко (1925-1931, «Преступление и наказание»), П. Н. Сакулина и Н. Ф. Бельчикова (1931, «Идиот»), А. С. Долинина (1935, «Братья Карамазовы»; 1977, «Подросток»), Л. Д. Опульской и Г. Ф. Коган (1970, «Преступление и наказание»). Позже этот же принцип отбора материала был продолжен в академическом ПСС.

6 В советской текстологии сразу и почти одновременно сложились две противоположные традиции публикации творческих записей: «предельно точное», постраничное, чтобы исключить редакторский произвол и ошибочное толкование, воспроизведение каждой страницы тетради, «как целого, как архивного документа» [Розенблюм, 1965: 53] (И. И. Гливенко, Е. Н. Коншина, Г. И. Чулков), названное критиками подобного подхода «формально-механическим копированием текстов», - и кропотливая, сложная попытка реконструкции "реальной картины творческого процесса», сопровождаемая перестановкой, иногда довольно серьезной, записей тетради (А. С. Долинин, П. Н. Сакулин, редакция «Литературного наследства»: В. Л. Комарович, Л. М. Розенблюм) (см.: [От редакции, 1965: 6], [Розенблюм, 1965: 53-54]).

7 Подобная работа над проектом создания цифрового архива рукописей Достоевского ведется в настоящее время в Петербурге в Институте русской литературы (Пушкинский Дом) РАН при поддержке Российского научного фонда (проект «Рабочие тетради Ф. М. Достоевского: первая полнотекстовая публикация автографов в их динамической транскрипции», под руководством С. А. Кибальника). Более полное освещение этого вопроса см.: [Тарасова, 2019], а также во вводных статьях на портале «Цифровой архив Ф. М. Достоевского» (URL: dostoevsky-archive): «Принципы публикации рукописей», «О рабочих тетрадях Достоевского». См. об этом: [Захаров].

9 См.: [Гроссман]. В. С. Нечаева и Б. В. Томашевский, занимавшиеся проблемами атрибуции статей из «Времени» и «Эпохи», работали с двумя неопубликованными приходно-расходными книгами по этим журналам, с 1929 по 1939 г. хранившимися в музее имени Достоевского в Москве (см.: [Томашевский: 561, 572, 595, 596, 608, 609, 611, 612]). См.: [Коншина: 37-39, 95, 177-178, 181-182, 187, 320, 325, 347-348].

11 Не были опубликованы расчеты из пяти записных тетрадей, не вошедших в публикацию т. 83 «Литературного наследства» (РГАЛИ. 212.1.5, 212.1.7; ОР РГБ. Ф. 93.I.2.5, 93.І.1.4, 93.І.1.5). Из напечатанных же тетрадей были сознательно исключены из публикации «редакторские заметки по журналу “Эпоха”, как представляющие «варианты уже имеющихся в предыдущей тетради» (ОР РГБ. Ф. 93.І.2.8), а также все «приходно-расходные дневники по продаже книг Достоевского (кассовые счета) из трех последних тетрадей» (РГАЛИ. Ф. 212.1.15, 212.1.16, 212.1.17) [От редакции, 1971: 6]. Кроме этих оговоренных редакцией «Литературного наследства» лакун, в тетрадях № IV (РГАЛИ. Ф. 212.1.4) и № VIII (РГАЛИ. Ф. 212.1.13) было пропущено при подготовке к публикации по 1 странице, также содержащих расчеты. Она будет предметом нашего анализа в следующем году.

13 Ее анализ см. в нашей прошлогодней статье: [Тарасова, Заваркина, Панюкова].

14 В издании «Литературного наследства» подобного типа записи комментируются кратко, либо комментарий к ним отсутствует (см., например: [ЛН, т. 83: 242, 347-348, 365]). В этой связи см. статью, посвященную редакторской деятельности Достоевского в журнале «Гражданин» и содержащую основательный анализ росписи номеров журнала (РГАЛИ. Ф. 212.1.11; записная тетрадь 1872-1875 гг.), с устранением неточностей публикации ЛН и подробным комментарием к каждой записи [Отливанчик], [Гонорарная роспись]. 
15 Именно на 1-й странице по обратной нумерации (с. 147 - по прямой) была сделана в 1909 г. дарственная надпись рукой А. Г. Достоевской.

16 Самые поздние записи в $3 K_{2}$ связаны с планами июльского и августовского номеров «Эпохи». Последняя авторская дата там: 19 августа 1864 г. (С. 87). Начиная с этого времени писатель заводит две записные тетради бо̀льшего формата, продолжая одновременно пользоваться и «третьей» записной книжкой (РГАЛИ. Ф. 212.1.3, 212.1.4; ОР РГБ. Ф. 93.І.2.8). Записи издательского характера в трех последних часто дополняют или дублируют друг друга.

17 С. 145 (с. 3 по обратной нумерации, чернилами) - 21-24 августа 1864 г.; 143 (5, чернилами, карандашом) - 25-26 августа; 142 (6, чернилами); 141 (7, чернилами) - 29 августа 3 сентября 1864 г.; 140 (8, чернилами) - 4-7 сентября 1864 г.; 139 (9, чернилами) - 7-14 и 17-19 сентября 1864 г.; 14 (135, чернилами) - 15 сентября 1864 г.; 138 (10, чернилами, карандашом) - 19-25 сентября 1864 г.; 137 (11, чернилами, карандашом) - 25 сентября - 6 октября 1864 г.; 84 (65, чернилами) - 6 октября 1864 г.; 136 (12, чернилами, карандашом) - 7-28 октября 1864 г.; 135 (13, чернилами) - 29 октября - 22 декабря 1864 г.; 134 (14, чернилами) - 31 декабря 1864 г. - 5 января 1865 г. (на этой же странице, в прямом направлении, позже вписаны наброски к «Преступлению и Наказанию»); 133 (15, чернилами) - 2 февраля 1865 г. (на этой же странице, в прямом направлении, позже вписаны наброски к «Преступлению и Наказанию»).

18 С. 7 (142, чернилами), 5 (144, чернилами, карандашом), 4 (145, чернилами, карандашом), 3 (146, чернилами, карандашом), 2 (147, карандашом), 131 (17, чернилами, карандашом), 129 (19, чернилами, карандашом). Перечисляем записи в том порядке, как они опубликованы в «Литературном наследстве» [ЛН, т. 83: 205-209].

19 С. 125 (23, чернилами), 126 (22, чернилами), 127 (21, чернилами), 128 (20, чернилами).

20 При просмотре записных книжек и тетрадей явственные автографы писателя были обнаружены в следующих: РГАЛИ. Ф. 212.1.5 (на форзаце записан в т. ч. адрес Анны Григорьевны Сниткиной, о чем она и упомянула в адресованной потомкам надписи на тетради), 212.1.7 <i> $>$ 212.1.9 <i $>$, 212.1.12, 212.1.15, 212.1.16, ОР РГБ. Ф. 93.I.1.5, 93.I.2.8.

21 Вариант, предложенный в проекте цифрового архива Достоевского: «Театрь 1 л.<i>».

22 Там же: вставка отнесена к записи в верхней строке (касающейся Зименко). Мы предлагаем другой вариант, исходя из двух соображений: 1) несмотря на встречающиеся (реже) в рукописях Достоевского вставки под строкой, в данном случае для подобного нет предпосылок: места над первой строкой с записью про Зименко вполне достаточно; 2) однако более весомым аргументом будет следующий: на соседней странице тетради, также в направлении, обратном основному, есть аналогичная запись (хронологически, видимо, более ранняя): «Өедорову въ Оренбургъ - Заплатить въ Январп» с. 1 (148).

23 Корреспондент Достоевского. 19 декабря 1864 г. А. В. Зименко обратился к писателю как редактору «Эпохи» с просьбой заплатить ему оставшуюся часть гонорара за повесть «Бутузка», вышедшую в журнале «Время» (1863, № 2 и 3). Достоевский вступил с ним в переписку. Однако настоящим автором «Бутузки» был писатель И. А. Салов, а Зименко выступал лишь посредником. Подробнее см.: [Андрианова].

24 Юлия Петровна Померанцева, урожденная Карепина (ум. 1873) - русская писательница, переводчица, редактор журнала «Модный свет». Дочь от первого брака Петра Андреевича Карепина, дальняя родственница братьев Достоевских: падчерица их сестры Варвары Михайловны Карепиной (урожд. Достоевской).

25 Григорьев А. А. Отживающие в литературе явления. Prolegomena. Д. В. Григорович // Э. 1864. Август. С. 1-26.

26 См.: [Тарасова, Заваркина, Панюкова]. 


\section{Список литературы}

1. Андрианова И. С. Из редакционной переписки «Времени» и «Эпохи»: братья Достоевские, А. В. Зименко, И. А. Салов // Неизвестный Достоевский. - 2018. - № 3. C. 180-194 [Электронный ресурс]. — URL: http://unknown-dostoevsky.ru/files/redaktor_ pdf/1541588823.pdf (01.10.2019). DOI: 10.15393/j10.art.2018.3721

2. Гроссман Л. П. Жизнь и труды Ф. М. Достоевского. Биография в датах и документах. М.; Л.: Academia, 1935. - 382 c.

3. Достоевский Ф. М. Полн. собр. соч.: в 30 т. - Л.: Наука, 1972-1990.

4. Достоевский: сочинения, письма, документы: словарь-справочник / сост. и науч. ред. Г. К. Щенников, Б. Н. Тихомиров. - СПб.: Пушкинский Дом, 2008. - 470 с.

5. Заваркина М. В. Проблемы хронологической атрибуции «второй» записной книжки Ф. М. Достоевского // Неизвестный Достоевский. - 2019. - № 2. - С. 5-39 [Электронный ресурс]. - URL: http://unknown-dostoevsky.ru/files/redaktor_pdf/1562145716.pdf (01.10.2019). DOI: 10.15393/j10.art.2019.4081

6. Записная книжка <№ 2> 1862-1864 гг. Записная тетрадь <№ 3> 1864-1865 гг. Записная книжка <№ 5> 1864-1865 гг. // Неизданный Достоевский. Записные книжки и тетради 1860-1881 гг. - М.: Наука, 1971. - С. 171-200, 201-242, 284-288. (Литературное наследство; т. 83)

7. Записные тетради Ф. М. Достоевского / подг. к печати Е. Н. Коншиной; комм. Н. И. Игнатовой и Е. Н. Коншиной. - М.; Л., 1935. - 474 с.

8. Захаров В. Н. Поэтика и жанр маргиналий в записных книжках и рабочих тетрадях Достоевского // Проблемы исторической поэтики. - 2018. - Т. 16. - № 3. - C. 85-100 [Электронный ресурс]. - URL: http://poetica.pro/files/redaktor_pdf/1538994799.pdf (01.10.2019). DOI: 10.15393/j9.art.2018.5461

9. [Нечаева В. С.] Описание рукописей Ф. М. Достоевского / под ред. В. С. Нечаевой. - М.: Изд-во АН СССР, 1957. - 589 с.

10. Нечаева В. С. Журнал М. М. и Ф. М. Достоевских «Эпоха». 1864-1865. - М.: Наука, 1975. - 304 c.

11. [Орнатская Т. И.] Рукою Достоевского / публ. Т. И. Орнатской // Достоевский. Материалы и исследования. - Л.: Наука, 1985. - Вып. 6. - С. 3-31.

12. Отливанчик А. В. Гонорарная роспись «Гражданина» (1873. №№ 23-39) как источник атрибуции анонимных и псевдонимных публикаций // Неизвестный Достоевский. 2016. — № 3. - C. 14-27 [Электронный ресурс]. — URL: http://unknown-dostoevsky.ru/ files/redaktor_pdf/1479813399.pdf (01.10.2019). DOI: 10.15393/j10.art.2016.2803

13. От редакции // Неизданный Достоевский. Записные книжки и тетради 1860-1881 гг. М.: Наука, 1971. - С. 5-8. (Литературное наследство»; т. 83)

14. От редакции // Ф. М. Достоевский в работе над романом «Подросток»: творческие рукописи. - М.: Наука, 1965. - С. 5-6. (Литературное наследство; т. 77)

15. Рейсер С. А. Русская палеография нового времени. - М.: Высшая школа, 1982. - 136 с. 
16. Розенблюм Л. М. Проблемы публикации записных книжек писателя (из опыта «Литературного наследства») // Современная текстология: теория и практика / ИМЛИ им. А. М. Горького РАН. - М.: Наследие, 1997. - С. 89-94.

17. Розенблюм Л. М. Творческая лаборатория Достоевского-романиста // Ф. М. Достоевский в работе над романом «Подросток»: творческие рукописи. - М.: Наука, 1965. - С. 7-56. (Литературное наследство; т. 77)

18. Розенблюм Л. М. Творческие дневники Достоевского // Неизданный Достоевский. Записные книжки и тетради 1860-1881 гг. - М.: Наука, 1971. - С. 9-92. (Литературное наследство; т. 83)

19. Розенблюм Л. М. Творческие дневники Достоевского. - М.: Наука, 1981. - 368 с.

20. Тарасова Н. А. Проблемы публикации рукописного текста Достоевского (на материале черновых рукописей) // Неизвестный Достоевский. - 2016. - № 4. - С. 3-22 [Электронный ресурс]. - URL: http://unknown-dostoevsky.ru/files/redaktor_ pdf/1482754553.pdf (01.10.2019). DOI: 10.15393/j10.art.2016.2861

21. Тарасова Н. А. Цифровой архив Достоевского: проблемы публикации рукописного текста в электронном издании // Филологические науки (Научные доклады высшей школы). - 2019. - № 2 (март). - C. 81-91 [Электронный ресурс]. - URL: http://dostoevsky-archive.ru/ru/publications/\%092652 (01.09.2019).

22. Тарасова Н. А., Заваркина М. В., Панюкова Т. В. Графические особенности рукописей Достоевского: материалы для информационной базы данных // Неизвестный Достоевский. - 2018. - № 4. - С. 17-69 [Электронный ресурс]. - URL: http:// unknown-dostoevsky.ru/files/redaktor_pdf/1545737853.pdf (01.10.2019). DOI: 10.15393/ j10.art.2018.3788

23. Тихомиров Б. Н. Петербургские адреса и адресаты Достоевского (К проблеме краеведческого комментирования адресных записей писателя) // Неизвестный Достоевский. - 2017. - № 4. - С. 90-140 [Электронный pecypc]. - URL: http:// unknown-dostoevsky.ru/files/redaktor_pdf/1514461706.pdf (01.10.2019). DOI: 10.15393/ j10.art.2017.3361

24. Тихомиров Б. Н. Петербургские адреса и адресаты Достоевского (К проблеме краеведческого комментирования адресных записей писателя). Статья вторая // Неизвестный Достоевский. - 2018. - № 3. - С. 56-105 [Электронный ресурс]. URL: http:// unknown-dostoevsky.ru/files/redaktor_pdf/1541001296.pdf (01.10.2019). DOI: $10.15393 /$ j10. art.2018.3701

25. Томашевский Б. В. Достоевский редактор // Достоевский Ф. М. Полн. собр. художественных произведений / под ред. Б. Томашевского и К. Халабаева. - М.; Л.: Госиздат, 1930. - Т. 13: Статьи. - С. 559-614.

26. Ф. М. Достоевский <Гонорарная роспись №№ 23-39 «Гражданина» 1873 г. Из записной тетради 1872-1875 гг.> / подг. текста и примеч. А. В. Отливанчика // Неизвестный Достоевский. - 2016. - № 3. - С. 28-69 [Электронный ресурc]. - URL: http://unknown-dostoevsky.ru/files/redaktor_pdf/1479813482.pdf (01.10.2019). DOI: 10.15393/j10.art.2016.2804

27. Фридлендер Г. М. Новые материалы из рукописного наследия художника и публициста // Неизданный Достоевский. Записные книжки и тетради 1860-1881 гг. М.: Наука, 1971. - С. 93-122. (Литературное наследство; т. 83) 
Marina V. Zavarkina

Petrozavodsk State University (Petrozavodsk, Russian Federation) mvnikulina@mail.ru

Tatiana V. Panyukova

Petrozavodsk State University (Petrozavodsk, Russian Federation)

aurinko75@mail.ru

Natalia A. Tarasova

The Institute of Russian Literature (Pushkinskiy Dom)

Russian Academy of Sciences

(Saint Petersburg, Russian Federation)

nsova74@mail.ru

\section{Graphical Peculiarities of Dostoevsky's Manuscripts (Based on the Materials of the Notebooks and Workbooks of the Years 1862-1865)}

Acknowledgements. The reported study was funded by RFBR according to the research project no. 18-012-00129

Abstract. This publication describes the preliminary results of graphical analysis carried out basing on the materials of Dostoevsky's workbooks of the first half of the 1860s, namely his "second" and "third" notebooks as well as one of his workbooks composed along with the previous ones (The Manuscripts Department of the Russian State Library. Funds 93.I.2.7, 93.I.2.8; The Russian State Archive of Literature and Arts. Fund 212.1.3). Via concrete examples it is shown how a new database on Dostoevsky's writing can become an effective tool of the analysis of "difficult readings" in the writer's autographs. The article considers the possibility of using two methods of representing the texts of Dostoevsky's notebooks in the graphic analysis of a particular group of records in these notebooks related to calculations and publishing activities of Dostoevsky. A comprehensive study of this little-studied group of records belonging to several notebooks kept at the same time allowed revealing some common features. The intermediate results of graphical analysis of the figures appeared in Dostoevsky's manuscripts are presented in the form of a table, complementing a similar hand lettering table compiled last year.

Keywords: F. M. Dostoevsky, hand written heritage, notebooks, workbooks, textual study, graphics, Illustrated Information database, publishing activity

About the authors: Zavarkina Marina V. $-\mathrm{PhD}$ in Philology, Specialist, WEB-laboratory of Institute of Philology, Petrozavodsk State University (pr. Lenina 33, Petrozavodsk, Republic of Karelia, 185910, Russian Federation); Panyukova Tatiana V. - Senior Editor of the Publishing House, Petrozavodsk State University (pr. Lenina 33, Petrozavodsk, Republic of Karelia, 185910, Russian Federation); Tarasova Natalia A. - Doctor of Philology, Leading Researcher, the Institute of Russian Literature (Pushkinskiy Dom) Russian Academy of Sciences (nab. Makarova 4, Saint Petersburg, 199034, Russian Federation)

Received: October 10, 2019

Date of publication: December 1, 2019

For citation: Zavarkina M. V., Panyukova T. V., Tarasova N. A. Graphical Peculiarities of Dostoevsky's Manuscripts (Based on the Materials of the Notebooks and Workbooks of the Years 1862-1865). In: Neizvestnyy Dostoevskiy [The Unknown Dostoevsky], 2019, no. 4, pp. 84-138. DOI: 10.15393/j10.art.2019.4301 (In Russ.) 


\section{References}

1. Andrianova I. S. From Editorial Correspondence Between "Vremya" and "Epokha": The Brothers Dostoevskys, Ardalion Zimenko, Iliya Salov. In: Neizvestnyy Dostoevskiy [The Unknown Dostoevsky], 2018, no. 3, pp. 180-194. Available at: http://unknown-dostoevsky.ru/files/redaktor_pdf/1541588823. pdf (accessed on October 1, 2019). DOI: 10.15393/j10.art.2018.3721 (In Russ.)

2. Grossman L. P. Zhizn' i trudy F. M. Dostoevskogo: biografiya $v$ datakh i dokumentakh [Life and Works of F. M. Dostoevsky: Biography in Terms of Dates and Documents]. Moscow, Leningrad, Academia Publ., 1935. 382 p. (In Russ.)

3. Dostoevskiy F. M. Polnoe sobranie sochineniy: $v 30$ tomakh [The Complete Works: in 30 Vols]. Leningrad, Nauka Publ., 1972-1990. (In Russ.)

4. Dostoevskiy: sochineniya, pis'ma, dokumenty: slovar'-spravochnik [Dostoevsky: Works, Letters and Documents: Dictionary and Reference Book]. St. Petersburg, Pushkinskiy Dom Publ., 2008. 470 p. (In Russ.)

5. Zavarkina M. V. The Problems of the Chronological Attribution of "the Second" Notebook of F. M. Dostoevsky. In: Neizvestnyy Dostoevskiy [The Unknown Dostoevsky], 2019, no. 2, pp. 5-39. Available at: http://unknown-dostoevsky.ru/files/redaktor_pdf/1562145716.pdf (accessed on October 1, 2019). DOI: 10.15393/j10.art.2019.4081 (In Russ.)

6. The Notebook no. 2 of 1862-1864. The Workbook no. 3 of 1864-1865. The Notebook no. 5 of 1864-1865. In: Neizdannyy Dostoevskiy. Zapisnye knizhki i tetradi 1860-1881 godov [The Unpublished Dostoevsky. Notebooks and Workbooks of 1860-1881]. Moscow, Nauka Publ., 1971, pp. 171-200, 201-242, 284-288. (Ser. “The Literary Heritage”; vol. 83) (In Russ.)

7. Konshina E. N., Ignatova N. I. Zapisnye tetradi F. M. Dostoevskogo, publikuemye Tsentral'nym arkhivnym upravleniem SSSR (tetradi №№ 1 i 4) i Publichnoy bibliotekoy SSSR imeni Lenina (tetradi №№ 2 i 3) [F. M. Dostoevsky's Notebooks Published by the Central Direction of Archives of the USSR (Notebooks № 1 and № 4) and by the Lenin State Library of the USSR (Notebooks № 2 and № 3)]. Moscow, Leningrad, Academia Publ., 1935. 474 p. (In Russ.)

8. Zakharov V. N. The Poetics and Genre of Marginalia in Fedor Dostoevsky's Notebooks and Workbooks. In: Problemy istoricheskoy poetiki [The Problems of Historical Poetics], 2018, vol. 16, no. 3, pp. 85-100. Available at: http://poetica.pro/files/redaktor_pdf/1538994799.pdf (accessed on October 1, 2019). DOI: 10.15393/j9.art.2018.5461 (In Russ.)

9. Nechaeva V. S. Opisanie rukopisey F. M. Dostoevskogo [The Description of Fedor Dostoevsky's Manuscripts]. Moscow, The Academy of Sciences of the USSR Publ., 1957. 589 p. (In Russ.)

10. Nechaeva V. S. Zhurnal M. M. i F. M. Dostoevskikh «Epokha» (1864-1865) [The Journal of Mikhail and Fedor Dostoevsky "Epokha" (1864-1865)]. Moscow, Nauka Publ., 1975. 303 p. (In Russ.)

11. Ornatskaya T. I. Dostoevsky's Handwriting. In: Dostoevskiy. Materialy i issledovaniya [Dostoevsky. Materials and Researches]. Leningrad, Nauka Publ., 1985, vol. 6, pp. 3-31. (In Russ.)

12. Otlivanchik A. V. The Fee List of “Grazhdanin” (1873. №№ 23-39) as a Source of Attribution of Anonymous and Pseudo-anonymous Publications. In: Neizvestnyy Dostoevskiy [The Unknown Dostoevsky], 2016, no. 3, pp. 14-27. Available at: http://unknown-dostoevsky.ru/files/redaktor_ pdf/1479813399.pdf (accessed on October 1, 2019). DOI: 10.15393/j10.art.2016.2803 (In Russ.)

13. Editorial Note. In: Neizdannyy Dostoevskiy. Zapisnye knizhki i tetradi 1860-1881 godov [The Unpublished Dostoevsky. Notebooks and Workbooks of 1860-1881]. Moscow, Nauka Publ., 1971, pp. 5-8. (Ser. “The Literary Heritage”; vol. 83) (In Russ.)

14. Editorial Note. In: F. M. Dostoevskiy v rabote nad romanom «Podrostok». Tvorcheskie rukopisi [Fedor Dostoevsky During His Work on the Novel "The Adolescent". Artistic Manuscripts]. Moscow, Nauka Publ., 1965, pp. 5-6. (Ser. “The Literary Heritage”; vol. 77) (In Russ.) 
15. Reyser S. A. Russkaya paleografiya novogo vremeni [Russian Paleography Criticism of the New Time]. Moscow, Vysshaya shkola Publ., 1982. 136 p. (In Russ.)

16. Rozenblyum L. M. The Problems of Publishing the Writer's Notebooks (Based on the Experience of "Literary Heritage"). In: Sovremennaya tekstologiya: teoriya i praktika [Modern Textual Criticism: Theory and Practice]. Moscow, Nasledie Publ., 1997, pp. 89-94. (In Russ.)

17. Rozenblyum L. M. The Creative Laboratory of Dostoevsky-Novelist. In: F. M. Dostoevskiy v rabote nad romanom «Podrostok». Tvorcheskie rukopisi [Fedor Dostoevsky During His Work on the Novel “The Adolescent". Artistic Manuscripts]. Moscow, Nauka Publ., 1965, pp. 7-56. (Ser. “The Literary Heritage"; vol. 77) (In Russ.)

18. Rozenblyum L. M. Fedor Dostoevsky's Artistic Diaries. In: Neizdannyy Dostoevskiy. Zapisnye knizhki i tetradi 1860-1881 godov [The Unpublished Dostoevsky. Notebooks and Workbooks of 1860-1881]. Moscow, Nauka Publ., 1971, pp. 9-92. (Ser. “The Literary Heritage”; vol. 83) (In Russ.)

19. Rozenblyum L. M. Tvorcheskie dnevniki Dostoevskogo [Fedor Dostoevsky's Artistic Diaries]. Moscow, Nauka Publ., 1981. 368 p. (In Russ.)

20. Tarasova N. A. The Problems of the Publication of Dostoevsky's Manuscripts (Based on Draft Manuscripts). In: Neizvestnyy Dostoevskiy [The Unknown Dostoevsky], 2016, no. 4, pp. 3-22. Available at: http://unknown-dostoevsky.ru/files/redaktor_pdf/1482754553.pdf (accessed on October 1, 2019). DOI: 10.15393/j10.art.2016.2861 (In Russ.)

21. Tarasova N. A. Digital Archive of Dostoevsky: Problems of Publication of a Handwritten Text in the Electronic Edition. In: Filologicheskie nauki (Nauchnye doklady vysshey shkoly) [Philological Sciences (Scientific Essays of Higher Education)], 2019, no. 2 (March), pp. 81-91. Available at: http:// dostoevsky-archive.ru/ru/publications/\%092652 (accessed on October 1, 2019). (In Russ.)

22. Tarasova N. A., Zavarkina M. V., Panyukova T. V. The Graphic Peculiarities of Dostoevsky's Manuscripts: Materials for Information Database. In: Neizvestnyy Dostoevskiy [The Unknown Dostoevsky], 2018, no. 4, pp. 17-69. Available at: http://unknown-dostoevsky.ru/files/redaktor_ pdf/1545737853.pdf (accessed on October 1, 2019). DOI: 10.15393/j10.art.2018.3788 (In Russ.)

23. Tikhomirov B. N. Dostoevsky's Addresses and Addressees in St. Petersburg (More on the Problem of Regional Comments on the Address Records of the Writer). In: Neizvestnyy Dostoevskiy [The Unknown Dostoevsky], 2017, no. 4, pp. 90-140. Available at: http://unknown-dostoevsky.ru/files/ redaktor_pdf/1514461706.pdf (accessed on October 1, 2019). DOI: 10.15393/j10.art.2017.3361 (In Russ.)

24. Tikhomirov B. N. Dostoevsky's Addresses and Addressees in St. Petersburg (More on the Problem of Regional Comments on the Address Records of the Writer). Article Two. In: Neizvestnyy Dostoevskiy [The Unknown Dostoevsky], 2018, no. 3, pp. 56-105. Available at: http://unknown-dostoevsky.ru/ files/redaktor_pdf/1541001296.pdf (accessed on October 1, 2019). DOI: 10.15393/j10. art.2018.3701 (In Russ.)

25. Tomashevskiy B. V. Dostoevsky is the Editor. In: Dostoevskiy F. M. Polnoe sobranie khudozhestvennykh proizvedeniy [Dostoevskiy F. M. The Complete Works of Fiction]. Moscow, Leningrad, Gosizdat Publ., 1930, vol. 13: Articles, pp. 559-614. (In Russ.)

26. Dostoevsky F. M. <The Fee List №№ 23-39 of “Grazhdanin”, 1873. From the Sketch-Book of 1872-1875>. Preparation of the Text and Notes of A. V. Otlivanchik. In: Neizvestnyy Dostoevskiy [The Unknown Dostoevsky], 2016, no. 3, pp. 28-69. Available at: http://unknown-dostoevsky.ru/files/redaktor_ pdf/1479813482.pdf (accessed on October 1, 2019). DOI: 10.15393/j10.art.2016.2804 (In Russ.)

27. Fridlender G. M. New Materials From the Handwritten Heritage of the Artist and Publicist. In: Neizdannyy Dostoevskiy. Zapisnye knizhki i tetradi 1860-1881 gg. [The Unpublished Dostoevsky. Notebooks and Workbooks of 1860-1881]. Moscow, Nauka Publ., 1971, pp. 93-122. (Ser. "Literary Heritage”; vol. 83) (In Russ.) 